This is an electronic reprint of the original article. This reprint may differ from the original in pagination and typographic detail.

\author{
Author(s): Kolari, Kalle; Sahamies, Joona; Kalenius, Elina; Novikov, Alexander S.; Kukushkin, \\ Vadim Yu; Haukka, Matti
}

Title: $\quad$ Metallophilic interactions in polymeric group 11 thiols

Year: $\quad 2016$

Version:

Please cite the original version:

Kolari, K., Sahamies, J., Kalenius, E., Novikov, A. S., Kukushkin, V. Y., \& Haukka, M. (2016). Metallophilic interactions in polymeric group 11 thiols. Solid State Sciences, 60(October), 92-98. https://doi.org/10.1016/j.solidstatesciences.2016.08.005

All material supplied via JYX is protected by copyright and other intellectual property rights, and duplication or sale of all or part of any of the repository collections is not permitted, except that material may be duplicated by you for your research use or educational purposes in electronic or print form. You must obtain permission for any other use. Electronic or print copies may not be offered, whether for sale or otherwise to anyone who is not an authorised user. 


\section{Accepted Manuscript}

Metallophilic interactions in polymeric group 11 thiols

Kalle Kolari, Joona Sahamies, Elina Kalenius, Alexander S. Novikov, Vadim Yu Kukushkin, Matti Haukka

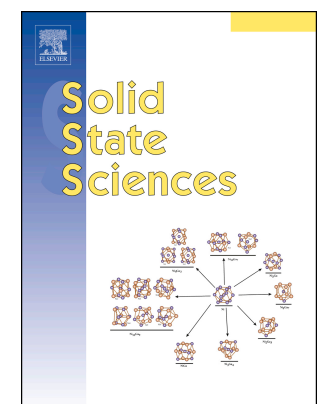

PII:

S1293-2558(16)30046-2

DOI:

10.1016/j.solidstatesciences.2016.08.005

Reference: SSSCIE 5358

To appear in: Solid State Sciences

Received Date: 8 March 2016

Revised Date: 2 August 2016

Accepted Date: 7 August 2016

Please cite this article as: K. Kolari, J. Sahamies, E. Kalenius, A.S. Novikov, V.Y. Kukushkin, M. Haukka, Metallophilic interactions in polymeric group 11 thiols, Solid State Sciences (2016), doi: 10.1016/ j.solidstatesciences.2016.08.005.

This is a PDF file of an unedited manuscript that has been accepted for publication. As a service to our customers we are providing this early version of the manuscript. The manuscript will undergo copyediting, typesetting, and review of the resulting proof before it is published in its final form. Please note that during the production process errors may be discovered which could affect the content, and all legal disclaimers that apply to the journal pertain. 


\title{
Metallophilic interactions in polymeric group 11 thiols
}

\author{
Kalle Kolari ${ }^{\mathrm{a}}$, Joona Sahamies ${ }^{\mathrm{a}}$, Elina Kalenius ${ }^{\mathrm{a}}$, Alexander S. Novikov ${ }^{\mathrm{b}}$, Vadim Yu. \\ Kukushkin $^{\mathrm{b}}$, and Matti Haukka ${ }^{\mathrm{a} *}$ \\ ${ }^{\text {a }}$ University of Jyvaskyla, Department of Chemistry, P. O. Box 35, FI-40014, University of Jyvaskyla, Finland \\ e-mail: matti.o.haukka@jyu.fi \\ ${ }^{\mathrm{b}}$ Institute of Chemistry, Saint Petersburg State University, Universitetskaya Nab. 7/9, 199034 Saint Petersburg, \\ Russian Federation
}

KEYWORDS Cu, Ag, Au, 4-pyridinethiol, metallophilic interactions

\begin{abstract}
Three polymeric group 11 transition metal polymers featuring metallophilic interactions were obtained directly via self-assembly of metal ions and 4-pyridinethiol ligands. In the cationic $\left[\mathrm{Cu}_{2}(\mathrm{~S}-\mathrm{pyH})_{4}\right]_{\mathrm{n}}{ }^{2+}$ with $\left[\mathrm{ZnCl}_{4}\right]_{\mathrm{n}}{ }^{2-}$ counterion (1) and in the neutral $[\mathrm{Ag}(\mathrm{S}-\mathrm{py})(\mathrm{S}-\mathrm{pyH})]_{\mathrm{n}}(\mathbf{2})$ 4-pyridinethiol (S-pyH) and its deprotonated form (S-py) are coordinated through the sulfur atom. Both ligands are acting as bridging ligands linking the metal centers together. In the solid state, the gold(I) polymer $\left[\mathrm{Au}(\mathrm{S}-\mathrm{pyH})_{2}\right] \mathrm{Cl}(3)$ consists of the repeating cationic $\left[\mathrm{Au}(\mathrm{S}-\mathrm{pyH})_{2}\right]^{+}$units held together by aurophilic interactions. Compound $\mathbf{1}$ is a zig-zag chain, whereas the metal chains in the structures of $\mathbf{2}$ and 3 are linear. The protonation level of the thiol ligand had an impact on the crystallization of polymers. Both nature of the metal center and reaction conditions affected the polymerization. QTAIM analysis confirmed direct metal-metal contacts only in polymers $\mathbf{1}$ and $\mathbf{3}$. In polymer $\mathbf{2}$, no theoretical evidence of argentophilic contacts was obtained even though the $\mathrm{Ag} \cdots \mathrm{Ag}$ distance was found to be less than sum of the Bondi's van der Waals radius of silver.
\end{abstract}

\section{Introduction}

Metallopolymers is a class of compounds that covers a wide range of metal containing polymeric systems [1]. The structures vary from mainly organic polymers with metal centers in the main or side chain, to systems with direct covalent metal-metal bonds [2a, b,c,d], and non-covalent metallophilic assemblies of metal species [2,e,f,g,h]. The motivation for preparation of metallopolymers lie in their versatile properties, such as conductivity [2i] and photophysical properties [3] as well as their magnetic [4] and catalytic [5] behavior. These properties determined applications of metallopolymers such as photovoltaic cells, catalysts and light emitting devices [1-5].

In most cases, the key properties arise from the interactions between metal centers $[6 a, b, c]$. These interactions can be achieved by linking metal centers together with a suitable (usually conjugated) ligands and building coordination polymers [6d]. Another approach is to exploit direct metal-metal contacts. These contacts can either be covalent metal-metal bonds or non-covalent metallophilic contacts [6e]. Polymeric transition metal systems that have only 
covalent metal-metal bonds between the repeating units are relatively rare [2b, d]. More commonly, metal-metal contacts are further supported by suitable multidentate ligands that can force metal centers close to each other. Multidentate nitrogen ligands are widely used supporters [6f, g,h,2h]. However, metals can also be brought together by single atom bridges. Simple bridging ligands such as halides, pseudo halides or sulfur containing ligands can be used in this type of systems [7]. In metal thiols and closely related coordination compounds, the soft sulfur atom is readily available for coordination and capable to act as bridging atom through its free electron pairs [8a-d]. Usually, thiol ligands can be relatively easily modified to adjust their electronic and steric properties. Because of this adjustability, thiols are excellent components for coordination chemistry [8e-i]. Heterocyclic thiols provide particularly versatile group of thiol ligands [9-12].

The 4-pyridine thiol is one of the commonly used heterocyclic thiol ligand. It can exist in different tautomeric forms, thiol (A), thione (B) and zwitterionic (C) forms (Fig 1).<smiles>Sc1ccncc1</smiles><smiles>S=c1cc[nH]cc1</smiles>

A<smiles>[S-]c1cc[nH+]cc1</smiles>

C

Figure 1. Schematic representation of tautomeric forms of 4-pyridinethiol.

Removal of the NH proton from 4-pyridinethiol opens up a possibility to use both of softer sulfur and harder nitrogen for coordination. Therefore, pyridinethiols have drawn attention as potential ambidentate ligands [13] exhibiting interesting spectroscopic [14a] and electrochemical [14b] behavior. Due to exocyclic sulfur and heterocyclic nitrogen donor, pyridine thiols have also been successfully exploited as ditopic ligands [15] for oligomeric and polymeric metal systems. Polynuclear species combining different metals by thiols have been used for example in catalytic [16a], pharmaceutical [16b], biochemical [16c], luminescent [16d], and magnetic [16e] materials and also as precursors for silver chalconides [16f]. One of the potential applications of thiols is to use them as supporting singleatom linking ligands in metallophilic polymers.

Metallophilicity can be described as attraction between closed shell or pseudo closed shell $d^{10}$ or $d^{8}$ transition metal cations. [17a] Strength of a metallophilic interaction is typically comparable to hydrogen bonds and it is clearly stronger than van der Waals interactions [17a]. Metallophilic interactions have been widely studied by the means of spectroscopic techniques [17a,6c], computational chemistry [17b-e] and structural studies [17f, g]. Metallophilicity is considered to be mainly a dispersion force with electron correlation effects [18]. Structurally metallophilicity can favor formation of various extended polynuclear structures including dimers, 1D chains, 2D sheets, 3D networks or molecular aggregates. [19] 
In this paper, we describe generation of linear and pseudolinear group 11 metallopolymers supported by sulfur coordinated 4-pyridinethiols. The primary goal was generation of novel metallophilic interactions due to application of the thiols that serve as molecular staples bringing together two metal atoms. The impact of the metal center and reaction conditions to the formation of polymers and their solid state structures are also briefly discussed.

\section{Materials and methods}

\section{General remarks}

Reagents were used as received. Acetonitrile and methanol were HPLC grade. Purity of ethanol and dichlromethane were $99.5 \%$. NMR spectra were recorded with a Bruker 500MHz NMR with BBFO probe under ambient conditions. Mass spectra were measured on an ABSciex QSTAR Elite ESI-Q-TOF MS.

\section{X-ray Structure Determinations}

The crystals of $\left[\mathrm{Cu}_{2}(\mathrm{~S}-\mathrm{pyH})_{4}\right]_{\mathrm{n}}\left[\mathrm{ZnCl}_{4}\right]_{\mathrm{n}}(\mathbf{1}),[\mathrm{Ag}(\mathrm{S}-\mathrm{py})(\mathrm{S}-\mathrm{pyH})]_{\mathrm{n}}(\mathbf{2})$, and $\left[\mathrm{Au}(\mathrm{S}-\mathrm{pyH})_{2}\right] \mathrm{Cl}(\mathbf{3})$ were immersed in cryooil, mounted in a MiTeGen loop and measured at 120-170 K. The X-ray diffraction data were collected on an Agilent Technologies Supernova or an Bruker AXS KappaApex diffractometers using $\mathrm{Cu} \mathrm{K \alpha}(\lambda=1.54184 \AA)$ or Mo $\mathrm{K} \alpha$ radiation $(\lambda=0.70173 \AA)$. The CrysAlisPro [20] or Denzo/Scalepack [21] program packages were used for cell refinements and data reductions. The structures were solved by charge flipping method using the SUPERFLIP [22] program or by direct methods using SHELXS-2014 [23] program. An empirical absorption correction based on equivalent reflections (CrysAlisPro [20] or SADABS [24]) was applied to all data. Structural refinements were carried out using SHELXL-2014 [23] with the Olex2 [25] and SHELXLE [26] graphical user interfaces. In 1, the NH and OH hydrogen atoms were located from the difference Fourier map but constrained to ride on their parent atoms, with $\mathrm{U}_{\text {iso }}$ $=1.5 \mathrm{U}_{\mathrm{eq}}$ (parent atom). In 3 the $\mathrm{NH}$ hydrogens were located from the difference Fourier map and refined isotropically. All other hydrogens were positioned geometrically and constrained to ride on their parent atoms, with $\mathrm{C}-\mathrm{H}=0.98-1.00 \AA, \mathrm{N}-\mathrm{H}=0.88 \AA$, and $\mathrm{U}_{\text {iso }}=1.2-1.5$ Ueq (parent atom). The crystallographic details are summarized in Table 1. 
Table 1. Crystal data for $\mathbf{1}-\mathbf{3}$.

\begin{tabular}{|c|c|c|c|}
\hline & 1 & 2 & 3 \\
\hline empirical formula & $\mathrm{C}_{22} \mathrm{H}_{26} \mathrm{Cl}_{4} \mathrm{Cu}_{2} \mathrm{~N}_{4} \mathrm{O}_{1} \mathrm{~S}_{4} \mathrm{Zn}$ & $\mathrm{C}_{10} \mathrm{H}_{9} \mathrm{AgN}_{2} \mathrm{~S}_{2}$ & $\mathrm{C}_{10} \mathrm{H}_{10} \mathrm{AuClN} \mathrm{S}_{2}$ \\
\hline fw & 824.96 & 329.18 & 454.74 \\
\hline temp $(\mathrm{K})$ & $123(2)$ & $170(2)$ & $120(2)$ \\
\hline$\lambda(\AA)$ & 1.54184 & 0.71073 & 1.54184 \\
\hline cryst syst & Monoclinic & Orthorhombic & Monoclinic \\
\hline space group & $\mathrm{P} 2 / 1 \mathrm{n}$ & Ibam & $\mathrm{P} 2 / 1 / \mathrm{c}$ \\
\hline$a(\AA)$ & $10.0163(3)$ & $12.1624(6)$ & $16.9203(6)$ \\
\hline$b(\AA)$ & $10.0845(3)$ & $13.7874(10)$ & $11.3649(5)$ \\
\hline$c(\AA)$ & $29.8809(13)$ & $6.3879(4)$ & $6.7730(3)$ \\
\hline$\alpha(\mathrm{deg})$ & 90 & 90 & 90 \\
\hline$\beta(\operatorname{deg})$ & $95.051(3)$ & 90 & $99.647(4)$ \\
\hline$\gamma(\operatorname{deg})$ & 90 & 90 & 90 \\
\hline$V\left(\AA^{3}\right)$ & $3006.54(19)$ & $1071.17(12)$ & $1284.02(10)$ \\
\hline Z & 4 & 4 & 4 \\
\hline$\rho_{\text {calc }}\left(\mathrm{Mg} / \mathrm{m}^{3}\right)$ & 1.823 & 2.041 & 2.352 \\
\hline$\mu(\operatorname{Mo~K} \alpha)\left(\mathrm{mm}^{-1}\right)$ & 8.656 & 2.234 & 26.271 \\
\hline No. reflns. & 12623 & 7680 & 5014 \\
\hline Unique reflns. & 6128 & 849 & 2585 \\
\hline $\operatorname{GOOF}\left(\mathrm{F}^{2}\right)$ & 1.022 & 1.126 & 1.072 \\
\hline $\mathrm{R}_{\text {int }}$ & 0.0926 & 0.0640 & 0.0961 \\
\hline $\mathrm{R}^{\mathrm{a}}(I \geq 2 \sigma)$ & 0.0347 & 0.0253 & 0.0381 \\
\hline $\mathrm{wR} 2^{\mathrm{b}}(I \geq 2 \sigma)$ & 0.0878 & 0.0615 & 0.0918 \\
\hline $\begin{array}{l}\text { Largest diff. peak } \\
\text { and hole eA }\end{array}$ & $0.589 /-0.63$ & $0.457 /-0.517$ & $1.811 /-1.340$ \\
\hline
\end{tabular}

\section{Mass spectrometry}

Mass spectrometry experiments were performed on ABSciex QSTAR Elite ESI-Q-TOF mass spectrometer equipped with an API 200 TurboIonSpray ESI source from AB Sciex (former MDS Sciex) in Concord, Ontario (Canada). The samples for the MS measurements were prepared either by dilution in $\mathrm{MeCN}(\mathbf{1}, 12.9 \mu \mathrm{M})$ or $\mathrm{MeOH}(\mathbf{3}$, concentration unknown due to low solubility). The samples were injected into the ESI source with a flow rate of $5 \mu \mathrm{L} / \mathrm{min}$. The parameters were optimized to get maximum abundance of the ions under study. Room-temperature dinitrogen was used as nebulization. The measurement and data handling was accomplished with Analyst ${ }^{\circledR}$ QS 2.0 Software. Mass spectra were externally calibrated by ESI Tuning mix (Agilent Technologies). The compositions of the ions were verified by comparing experimental $\mathrm{m} / \mathrm{z}$ values and isotopic patterns with the theoretically calculated. In CID experiments, low resolution isolation in quadrupole Q1 was performed and the isolated ions were activated by CE- 
values from 10 to 40. Dinitrogen was used as a collision gas in the Q2 quadrupole (5.0 psi) and the product ions were detected by TOF scans.

\section{Computational details}

The single point calculations for model clusters has been carried out at the DFT level of theory using the M06 functional [27] (this functional describes reasonably weak dispersion forces and non-covalent interactions) with the help of the Gaussian-09 [28] program package. The experimental X-ray geometries were used as starting points. The calculations were carried out using DZP-DKH basis sets [29] for all atoms. No symmetry operations have been applied. The topological analysis of the electron density distribution with the help of the atoms in molecules (QTAIM) method developed by Bader [30] has been performed by using the Multiwfn program (version 3.3.4) [31]. The Cartesian atomic coordinates of the used model structures presented in the supporting material.

\section{Syntheses}

The aim of this study was to study possibilities to obtain metallopolymers that contain metallophilic contacts via selfassembly of metal-ions and the ligand. Thus, reactions were not optimized for maximum yields and purities. According to the ${ }^{1}$ HNMR (Figs. 1 and 2 in ESI), the crude products of $\mathbf{1}$ and $\mathbf{3}$ contained unreacted 4-pyridylthiol, 4,4'-dipyridyldisulfide, and 4-pyridylsulfide as the main impurities. ${ }^{1}$ HNMR spectra also revealed presence of residual solvents in the crude product. ${ }^{1} \mathrm{HNMR}$ spectrum of product 3 shows second order ${ }^{1} \mathrm{H}$ coupling and differ from previously reported chemical shifts due to solvent effects. Because of decomposition of $\mathbf{3}$ in DMSO the ${ }^{1} \mathrm{HNMR}$ was measured in 4-d MeOH. The silver polymer 2 was insoluble in most common solvents and no ${ }^{1} \mathrm{HNMR}$ spectrum in solution could be obtained. ATR-IR analysis was performed of polymer 2 (Fig. 4 in ESI).

\section{$\left[\mathrm{Cu}_{2}(\mathrm{~S}-\mathrm{pyH})_{4}\right]_{\mathrm{n}}\left[\mathrm{ZnCl}_{4}\right]_{\mathrm{n}}(\mathbf{1})$}

A solution of $\mathrm{CuCl}_{2} \cdot 2 \mathrm{H}_{2} \mathrm{O}(0.06 \mathrm{mmol}, 10 \mathrm{mg})$ in $\mathrm{MeCN} / \mathrm{EtOH}$ mixture (3:1 ratio, $\left.3 \mathrm{~mL}\right)$ was added to a solution of 4pyridinethiol $(0.3 \mathrm{mmol}, 33 \mathrm{mg})$ in $3 \mathrm{~mL}$ of same solvent mixture. The reaction mixture was stirred for $5 \mathrm{~min}$. Additional $5 \mathrm{~mL}$ of solvent mixture was added to the reaction flask cautiously without mixing until two distinct layers of solutions was formed. $\mathrm{ZnCl}_{2}(0.12 \mathrm{mmol}, 16 \mathrm{mg})$ was dissolved in $9 \mathrm{~mL}$ of $3: 1$ solvent mixture of acetonitrile/ethanol. Solution containing zinc chloride was then carefully added to the reaction mixture and the flask was closed with a rubber septa and the solution was left to stand at room temperature. X-ray quality yellow orange crystals were obtained within three days directly from the reaction mixture. Crystals were filtered and washed 3 times with $1 \mathrm{~mL}$ of 3:1 acetonitrile/ethanol mixture and dried under vacuum overnight. The crude solid product of complex $\mathbf{1}$ contained residues crystallization solvents $\mathrm{EtOH}, \mathrm{MeCN}$, and water. Several crystals of $\mathbf{1}$ were analyzed by single crystal X-ray diffraction and in these structures the ratio of solvents of crystallization varied depending on the drying time. The best structure solution was obtained from a crystal that incorporated only disordered EtOH. The sample used for the elemental analysis, in turn, contained only MeCN. That was confirmed by ${ }^{1} \mathrm{H}$ NMR. The yield of 1 was $44 \%(20.4 \mathrm{mg}) .{ }^{1} \mathrm{H}$ NMR (MeOD): $8.54(\mathrm{~d}, 2 \mathrm{H}, \mathrm{J}=6.6 \mathrm{~Hz}), 8.62$ (d, 2H, J=6.4 Hz). Elemental analysis calc. for $\left[\mathrm{Cu}_{2}(\mathrm{~S}-\mathrm{pyH})_{4}\right]_{\mathrm{n}}{ }^{2+}\left[\mathrm{ZnCl}_{4}\right]_{\mathrm{n}}{ }^{2-} \cdot 0.5 \mathrm{MeCN} \mathrm{C}: 31.55 \%, \mathrm{H}: 2.71 \%$ and $\mathrm{N}: 7.88 \%$ found C: $31.35 \%, \mathrm{H}: 2.88 \%$ and $\mathrm{N}$ : $7.55 \%$. 
$[\operatorname{Ag}(\mathrm{S}-\mathrm{py})(\mathrm{S}-\mathrm{pyH})]_{\mathbf{n}}(\mathbf{2})$

$\mathrm{AgNO}_{3}(0.09 \mathrm{mmol}, 15 \mathrm{mg})$ was dissolved separately in $3 \mathrm{~mL}$ of acetonitrile and 4-pyridinethiol $(0.3 \mathrm{mmol}, 33 \mathrm{mg})$ in $5 \mathrm{~mL}$ of ethanol. Concentrated $\mathrm{KOH}$ solution was prepared by weighing $0.538 \mathrm{~g}$ of $\mathrm{KOH}$ in $5 \mathrm{~mL}$ of water. Concentrated $\mathrm{KOH}$ solution $(4 \mathrm{~mL})$ was added into ligand solution to make the solution clearly basic. The $\mathrm{Ag}$ containing solution was then added rapidly to the basic ligand solution and the mixture was stirred overnight at room temperature. During this time the color of the reaction mixture turned from colorless to orange yellow. Small amount of precipitate formed during stirring was removed by filtering and the filtrate was left standing in a vessel closed with septa. The crystalline yellow orange product was obtained from the filtrate at room temperature within a week. The yield of 2 was $83 \%$ (24.6 mg). Elemental analysis calculated for $[\mathrm{Ag}(\mathrm{S}-\mathrm{py})(\mathrm{S}-\mathrm{pyH})]_{\mathrm{n}} \mathrm{C}: 36.48 \%, \mathrm{H}: 2.76 \%$ and N $8.51 \%$ found C: $36.45 \%, \mathrm{H}: 2.97 \%$ and N $8.64 \%$.

\section{$\left[\mathrm{Au}(\mathrm{S}-\mathrm{pyH})_{2}\right] \mathrm{Cl}(3)$}

The organic ligand, 4-pyridinethiol $(0.09 \mathrm{mmol}, 10 \mathrm{mg})$, was introduced in $8 \mathrm{~mL}$ of dichloromethane and stirred for $1 \mathrm{~h}$ until it was completely dissolved. $\mathrm{AuCl}(0.02 \mathrm{mmol}, 5 \mathrm{mg})$ was dissolved in $2 \mathrm{~mL}$ of acetonitrile and the metal solution was carefully layered onto the ligand solution after which the reaction vial was closed with septa. X-ray quality yellow crystals were formed within two weeks. Crystals were filtered, washed three times with $2 \mathrm{~mL}$ of acetonitrile and dried under vacuum overnight. The crude product of $\mathbf{3}$ contained always traces of water even if the Xray structure did not contain water of crystallization. NMR spectrum of compound 2 confirms presence of water in the sample. The product was not stable enough to be heated in vacuum. The yield of the product $\mathbf{3}$ was $30 \%(2.7 \mathrm{mg})$. ${ }^{1} \mathrm{H}$ NMR (MeOD) 8.03 (d, 4H, J=7.1 Hz), $7.97(\mathrm{~d}, 4 \mathrm{H}, \mathrm{J}=7.1 \mathrm{~Hz})$. MS +TOF $418.99 \mathrm{~m} / \mathrm{z}$. Elemental analysis calculated for $\left[\mathrm{Au}(\mathrm{S}-\mathrm{pyH})_{2}\right] \mathrm{Cl} \cdot \mathrm{H}_{2} \mathrm{O} \quad \mathrm{C}: 25.41 \%, \mathrm{H}: 2.56 \%$ and $\mathrm{N}: 5.93 \%$ found $\mathrm{C}: 25.66 \%, \mathrm{H}: 2.24 \%$ and N: $5.94 \%$.

\section{Results and discussion}

The general syntheses routes to compounds 1-3 are summarized in Scheme 1. Complexes $\left[\mathrm{Cu}_{2}(\mathrm{~S}-\mathrm{pyH})_{4}\right]_{\mathrm{n}}\left[\mathrm{ZnCl}_{4}\right]_{\mathrm{n}}(\mathbf{1})$ and $[\mathrm{Ag}(\mathrm{S}-\mathrm{py})(\mathrm{S}-\mathrm{pyH})]_{\mathrm{n}}(\mathbf{2})$ were prepared by dissolving metal salt and ligand separately in different solvents and then adding the metal complex solution into the solutions of the ligand (Scheme 1). The crystalline $\left[\mathrm{Au}(\mathrm{S}-\mathrm{pyH})_{2}\right] \mathrm{Cl}(\mathbf{3})$ was obtained by the layering metal containing acetonitrile solution onto the dichloromethane solution of the ligand. In the case of the Au complex, the product was obtained when the solutions were slowly mixed.

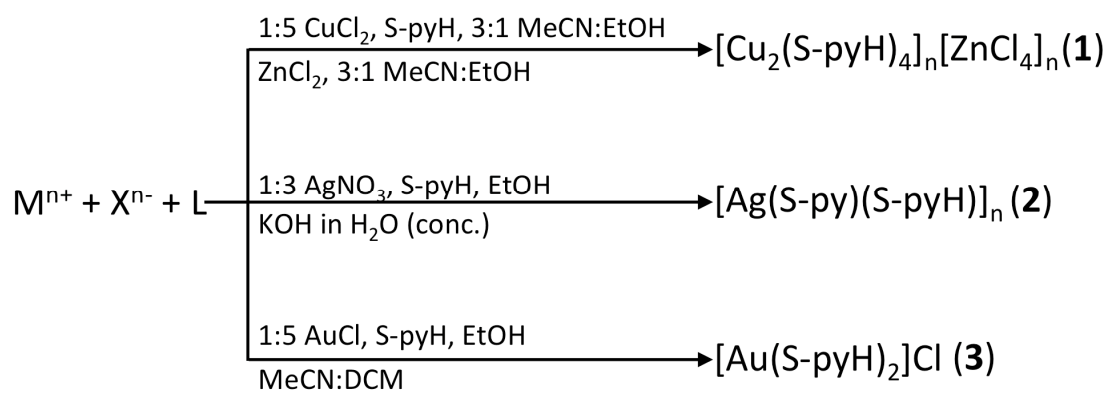

Scheme 1. Synthetic routes to $\mathbf{1}-\mathbf{3}$.

In the synthesis of silver system, 2, additional $\mathrm{KOH}$ was needed for deprotonation of 4-pyridinethiol ligand. The positive charges of the metal centers were balanced by the deprotonated S-py` ligands. To obtain crystalline neutral 
polymer, half of the thiol ligands had to be deprotonated. With copper (1) and gold (3), high quality crystals of the cationic products could be obtained without any deprotonation of the ligands. In these cases the positive charges of the metals were balanced by counter anions $\left[\mathrm{ZnCl}_{4}\right]^{2-}(\mathbf{1})$ and $\mathrm{Cl}^{-}(\mathbf{3})$.

\section{Cationic copper polymer $\left[\mathrm{Cu}_{2}(\mathrm{~S}-\mathrm{pyH})_{4}\right]_{\mathrm{n}}{ }^{2+}(1)$}

Several counterions including $\mathrm{PF}_{6}^{-}$, trifluoromethanesulfonate and lithium tetrakis(pentafluorophenyl)borate ethyl etherate were tested for crystallization of positively charged polymeric $\left[\mathrm{Cu}_{2}(\mathrm{~S}-\mathrm{pyH})_{4}\right]_{\mathrm{n}}{ }^{2+}(\mathbf{1})$ but high quality crystals were obtained only by using $\left[\mathrm{ZnCl}_{4}\right]^{2-}$ anion. Similar dinuclear $\mathrm{Cu}$ structure with chloride ion balancing the charge of the complex has been previously reported [32] but polymeric chain has remained unknown until now. In the polymeric structure of $\mathbf{1}$, the copper(I) centers are linked together by two S-coordinated 4-pyridinethiol ligands (SpyH) (Fig. 2). The structure also incorporates slightly disordered ethanol of crystallization, which is hydrogen bonded

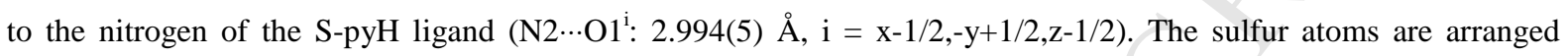
tetrahedrally around the copper atoms in the polymeric chain. These sulfur bridges pull metal centers closely together forming a 1D polymeric zig-zag chain (Fig. 2) with direct metal-metal contacts. The distances between the copper atoms are nearly identical throughout the chain varying from 2.6241(6) $\AA$ to 2.6283(6) $\AA$. Weak $\pi$ - $\pi$ interactions between the pyridine rings support the chain structure further. Short metal-metal distances between copper atoms indicate relatively strong cuprophilic interactions. The $\left[\mathrm{ZnCl}_{4}\right]^{2-}$ anion is interacting with the cationic polymer primarily through hydrogen bonds between the NH hydrogens of the S-PyH ligand and chlorides of the anionic zinc

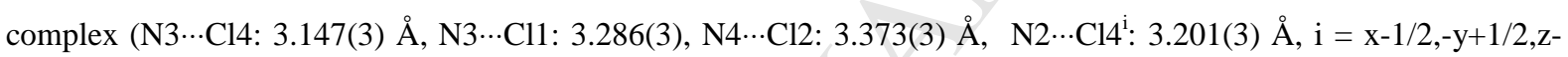
$1 / 2)$.
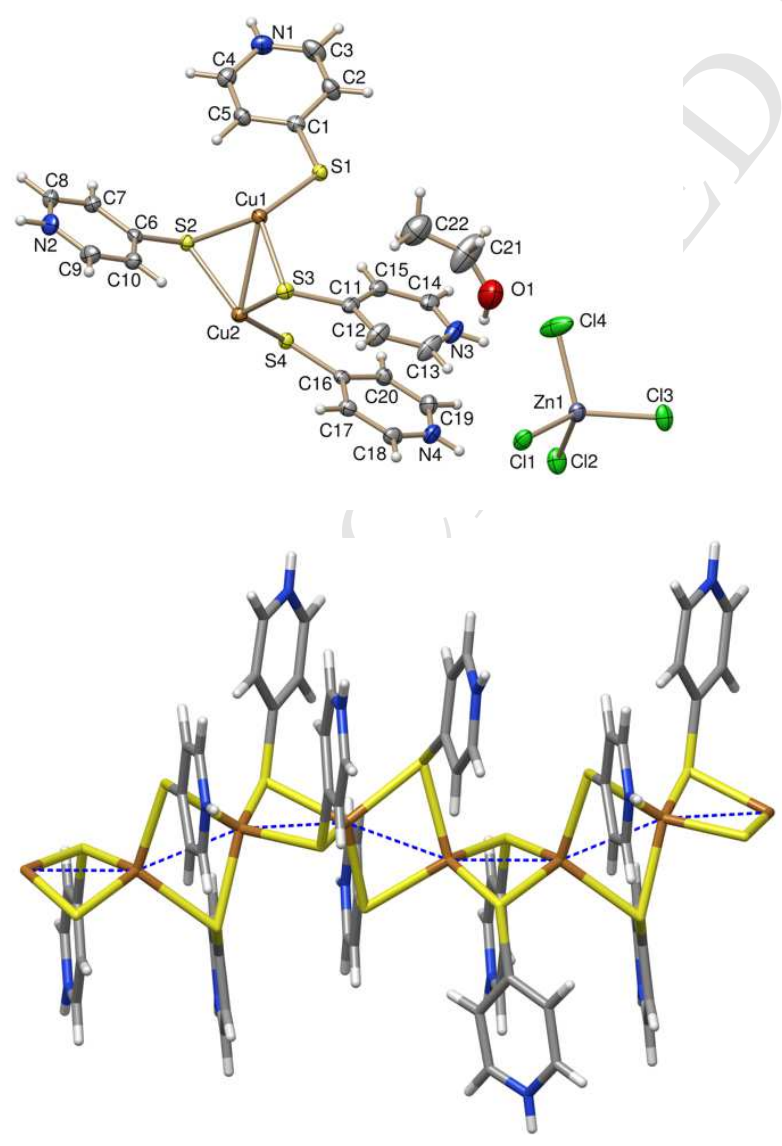
Figure 2. Top: The asymmetric unit of of $\left[\mathrm{Cu}_{2}(\mathrm{~S}-\mathrm{py})_{4}\right]_{\mathrm{n}}\left[\mathrm{ZnCl}_{4}\right]_{\mathrm{n}}$. The thermal ellipsoids are drawn at the $50 \%$ probability level. Bottom: The chain structure of $\mathbf{1}$. The solvent of crystallization and the courter anions have been omitted for clarity. Color codes for atoms in the figure are: $\mathrm{H}$ (white), $\mathrm{C}$ (gray), $\mathrm{N}$ (blue), $\mathrm{O}$ (red), $\mathrm{Cl}$ (green), $\mathrm{S}$ (yellow), $\mathrm{Cu}$ (Orange), and $\mathrm{Zn}$ (violet).

The polymeric character of $\mathbf{1}$ can also be seen from the mass spectrometric study. The ESI-TOF mass spectrum of $\mathbf{1}$ (Fig. 3) shows distribution of polymeric singly charged ions $\left[(\mathrm{S}-\mathrm{Py})_{n} \mathrm{Cu}_{\mathrm{n}}+\mathrm{Cu}\right]^{+},\left[(\mathrm{S}-\mathrm{Py})_{n} \mathrm{Cu} \mathrm{u}_{n}+\mathrm{H}\right]^{+}$, and $\left[(\mathrm{S}-\mathrm{Py})_{n} \mathrm{Cu} \mathrm{n}_{\mathrm{n}}+\right.$ $\left.\mathrm{NH}_{4}\right]^{+}(\mathrm{n}=3-6)$. The base peak of the spectrum is $\left[(\mathrm{S}-\mathrm{py})_{4} \mathrm{Cu}_{5}\right]^{+}$at $m / z, 758.68$, which agrees well with the theoretical value of $m / z, 758.67$ (for detailed analysis of mass accuracies see Table 2) and shows a nice fit to calculated isotopic distribution pattern. This ion also displays a structure related dissociation pattern in a CID (collision induced dissociation) experiment, in which the polymer fragments through consecutive eliminations of S-Py and (S-Py)Cu units (ESI, Fig. S3).

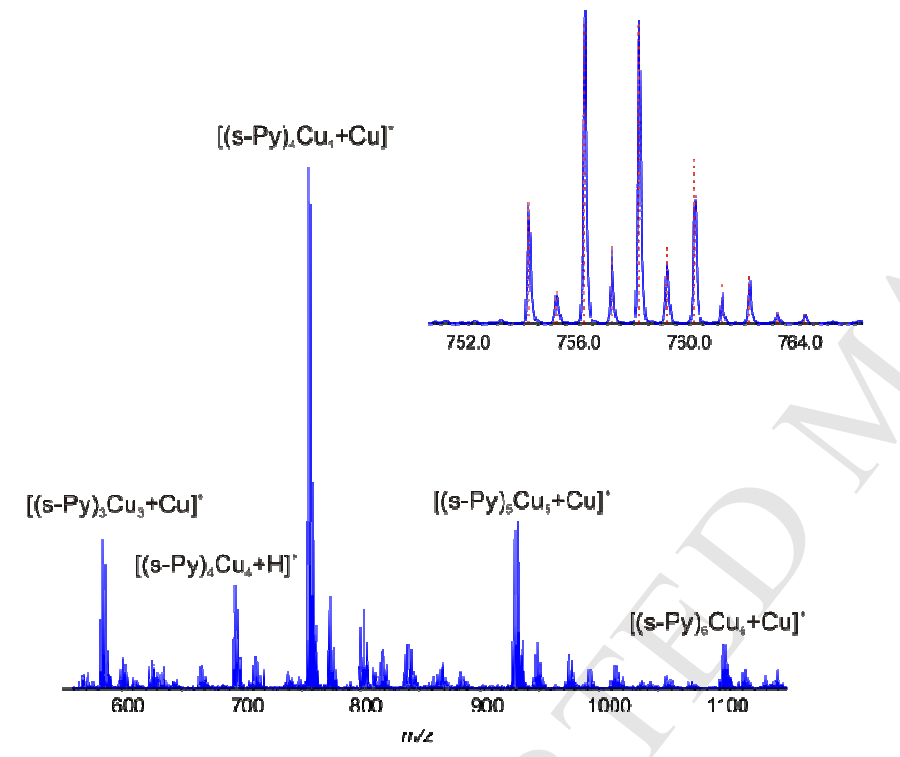

Figure 3. The ESI-QTOF MS spectrum of 1 in $\mathrm{MeCN}$. Inset showing the comparison between experimental and theoretical (red dotted lines) isotopic distribution for the $\left[(\mathrm{S}-\mathrm{Py})_{4} \mathrm{Cu}_{4}+\mathrm{Cu}\right]^{+}\left(\mathrm{C}_{20} \mathrm{H}_{16} \mathrm{~N}_{4} \mathrm{~S}_{4} \mathrm{Cu}_{5}^{+}\right)$.

Table 2. Experimental and theoretical $\mathrm{m} / \mathrm{z}$ values and mass accuracies for ions observed in mass spectra for $\mathbf{1}$ and $\mathbf{3}$.

\begin{tabular}{clcccc}
\hline sample & \multicolumn{1}{c}{ Ion } & composition & $\boldsymbol{m} / \boldsymbol{z}_{\text {exp }}$ & $\boldsymbol{m} / \boldsymbol{z}$ theor & mass accuracy $(\boldsymbol{m} / \boldsymbol{z})$ \\
\hline $\mathbf{1}$ & {$\left[(\mathrm{S}-\mathrm{Py})_{3} \mathrm{Cu}_{3}+\mathrm{Cu}\right]^{+}$} & $\mathrm{C}_{15} \mathrm{H}_{12} \mathrm{~N}_{3} \mathrm{~S}_{3} \mathrm{Cu}_{4}$ & 583.7365 & 583.7353 & -0.001 \\
& {$\left[(\mathrm{~S}-\mathrm{Py})_{4} \mathrm{Cu}_{4}+\mathrm{H}\right]^{+}$} & $\mathrm{C}_{20} \mathrm{H}_{17} \mathrm{~N}_{4} \mathrm{~S}_{4} \mathrm{Cu}_{4}$ & 694.7445 & 694.7495 & 0.005 \\
& {$\left[(\mathrm{~S}-\mathrm{Py})_{4} \mathrm{Cu}_{4}+\mathrm{Cu}\right]^{+}$} & $\mathrm{C}_{20} \mathrm{H}_{16} \mathrm{~N}_{4} \mathrm{~S}_{4} \mathrm{Cu}_{5}$ & 758.6782 & 758.6694 & -0.009 \\
& {$\left[(\mathrm{~S}-\mathrm{Py})_{5} \mathrm{Cu}_{5}+\mathrm{Cu}\right]^{+}$} & $\mathrm{C}_{25} \mathrm{H}_{20} \mathrm{~N}_{5} \mathrm{~S}_{5} \mathrm{Cu}_{6}$ & 931.6010 & 931.6055 & 0.005 \\
& {$\left[(\mathrm{~S}-\mathrm{Py})_{6} \mathrm{Cu}_{6}+\mathrm{Cu}\right]^{+}$} & $\mathrm{C}_{30} \mathrm{H}_{24} \mathrm{~N}_{6} \mathrm{~S}_{6} \mathrm{Cu}_{7}$ & 1104.5379 & 1104.5416 & 0.004 \\
\multirow{3}{*}{} & {$\left[(\mathrm{S}-\mathrm{PyH})_{2} \mathrm{Au}\right]^{+}$} & $\mathrm{C}_{10} \mathrm{H}_{10} \mathrm{~N}_{2} \mathrm{~S}_{2} \mathrm{Au}$ & 418.9944 & 418.9945 & 0.0001 \\
\hline
\end{tabular}

\section{Neutral silver polymer $[\operatorname{Ag}(\mathrm{S}-\mathrm{py})(\mathrm{S}-\mathrm{pyH})]_{\mathrm{n}}(2)$}

The polymeric $[\mathrm{Ag}(\mathrm{S}-\mathrm{py})(\mathrm{S}-\mathrm{pyH})]_{\mathrm{n}}(\mathbf{2})$ was crystallized in an orthorhombic space group Ibam. The asymmetric unit consists of one S-PyH or S-Py- ligand coordinated to a silver center via sulfur atoms. This give a repeating unit with two Ag atoms and one S-pyH and one S-Py ligands (Fig. 4). In other words, every second pyridyl ring in the chain is deprotonated compensating the charge of the silver centers. As in the case of copper polymer $\mathbf{1}$, the thiol ligands act as 
molecular staples bringing metal centres to close proximity. The silver-silver distances are practically identical throughout the chain varying from 3.1939(2) $\AA$ to 3.1940(2) $\AA\left(\operatorname{Ag} 1 \cdots A g 1^{\mathrm{i}}, \operatorname{Ag} 1 \cdots \mathrm{Ag} 1^{\mathrm{ii}}, \mathrm{i}=-\mathrm{x}+1,-\mathrm{y},-\mathrm{z}, \mathrm{ii}=-\mathrm{x}+1,-\mathrm{y},-\right.$ $\mathrm{z}+1)$. The Ag-Ag distances are clearly shorter than the sum of Bondi's van der Waals radii of silver atoms (3.44 $\AA$ ) bond. Just like in the case of the copper polymer, the chain structure is again further supported by weak $\pi-\pi$ interactions between the pyridyl rings. By contrast to the copper polymer, the Ag polymer is linear and the $\mathrm{Ag} \cdots \mathrm{Ag} \cdots \mathrm{Ag}$ angle is $180^{\circ}$. The sulfur ligands are again tetrahedrally arranged around the metal atoms in the polymeric structure. The neighboring chains are connected via hydrogen bonds between the protonated and deprotonated pyridyl nitrogens $\left(\mathrm{N} 1 \cdots \mathrm{N} 1^{\mathrm{iii}}: 2.675(4) \AA\right.$, iii $\left.=\mathrm{x}+1,-\mathrm{y}+1, \mathrm{z}\right)$.
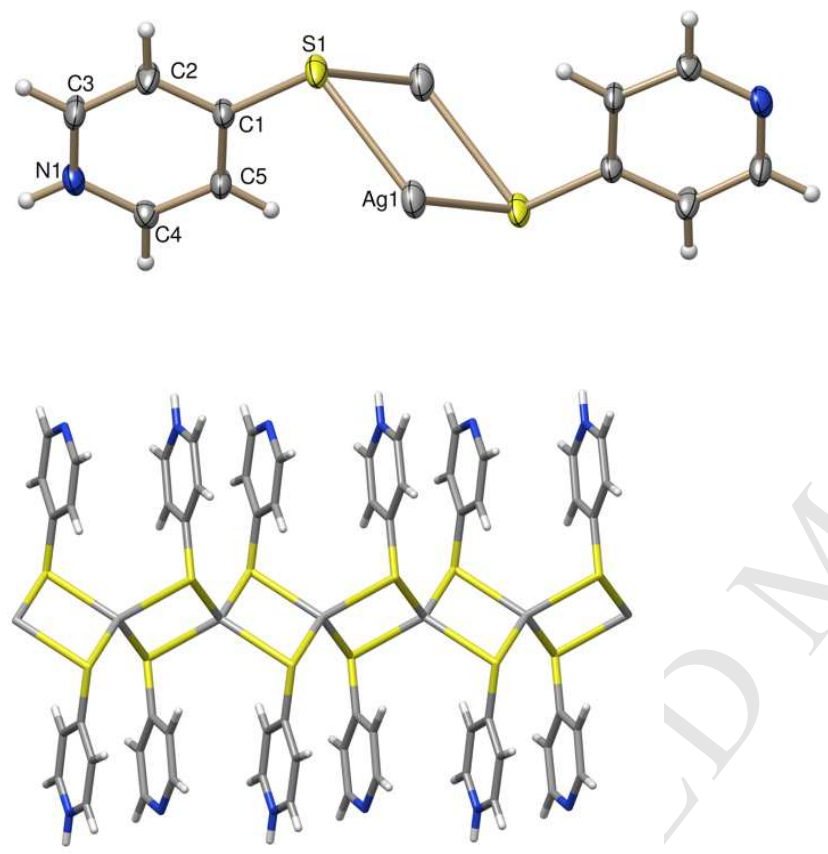

Figure 4. Top: The repeating unit of 2. The thermal ellipsoids are drawn at the $50 \%$ probability level. Bottom: The polymeric chain structure of $\mathbf{2}$. Color codes for atoms in the figure are: $\mathrm{H}$ (white), $\mathrm{C}$ (gray), $\mathrm{N}$ (blue), $\mathrm{S}$ (yellow), and $\mathrm{Ag}$ (grey).

\section{Cationic non-covalent polymer $\left[\mathrm{Au}(\mathrm{S}-\mathrm{pyH})_{2}\right]_{\mathrm{n}}{ }^{+}(3)$}

The structure of $\mathbf{3}$ has been reported earlier [33]. However, the current structure is based on higher quality data and therefore includes also the hydrogen atoms that were previously not detected. Because of the restricted coordination geometry of $\mathrm{Au}(\mathrm{I})$, the structure of the $\mathrm{Au}$ polymer $\left[\mathrm{Au}(\mathrm{S}-\mathrm{pyH})_{2}\right]_{\mathrm{n}} \mathrm{Cl}(3)$ differs from the $\mathrm{Cu}$ and $\mathrm{Ag}$ structures described above. The $\mathrm{Au}(\mathrm{I})$ favors linear coordination geometry and therefore, S-pyHs are not bridging but acting as terminal ligands (Fig. 5). In the crystal structure of $\mathbf{3}$, the cationic $\left[\mathrm{Au}(\mathrm{S}-\mathrm{pyH})_{2}\right]^{+}$units are stacked together forming a linear chains with weak aurophilic contacts ( $\mathrm{Au} \cdots \mathrm{Au}^{\mathrm{i}}: 3.4277(2) \AA, \mathrm{i}=x,-y+1 / 2, z+1 / 2$, Fig. 5). The chain structure is further supported by weak $\pi$ - $\pi$-interactions between the pyridyl rings. Despite the aurophilic and $\pi-\pi$ interactions the

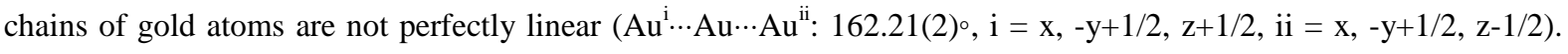
The asymmetric unit of $\mathbf{3}$ (Fig. 5) consist of two neutral S-pyH ligated to the Au center via the sulfur atom. The positive charge is compensated by the $\mathrm{Cl}^{-}$anion, which is hydrogen bonded to the NH hydrogens of the pyridyl rings 


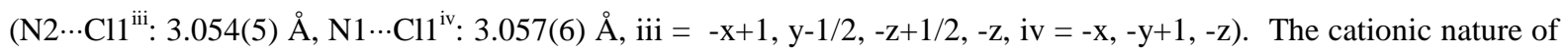
the gold complex is evident also according to positive polarization ESI-MS mass spectra, which display [Au(S$\left.\mathrm{PyH})_{2}\right]^{+}$ion at $m / z 419$ as a single peak (Fig. 6).
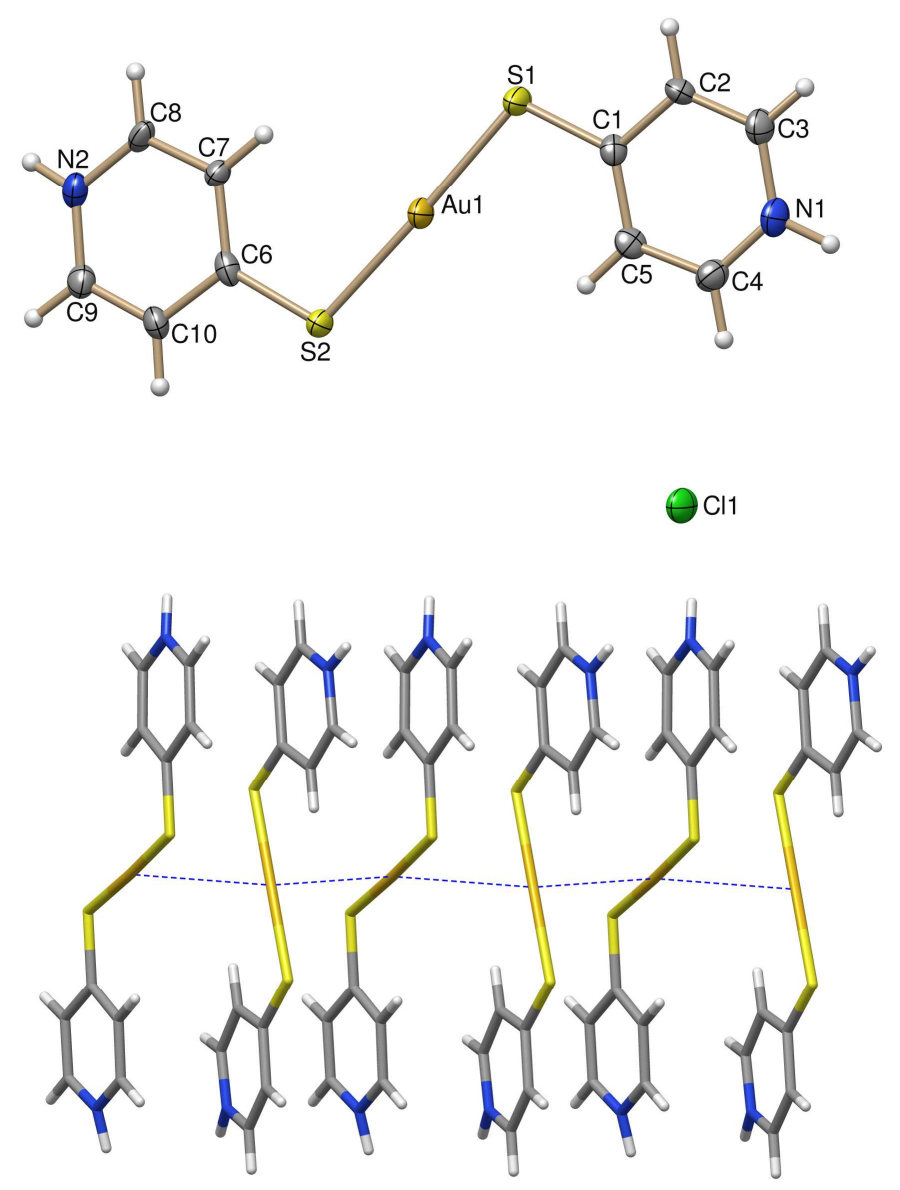

Figure 5. Top: The molecular unit of $\mathbf{3}$. The thermal ellipsoids are drawn at the 50\% probability level. Bottom: The chain structure of $\mathbf{3}$. The counterions were omitted for clarity.

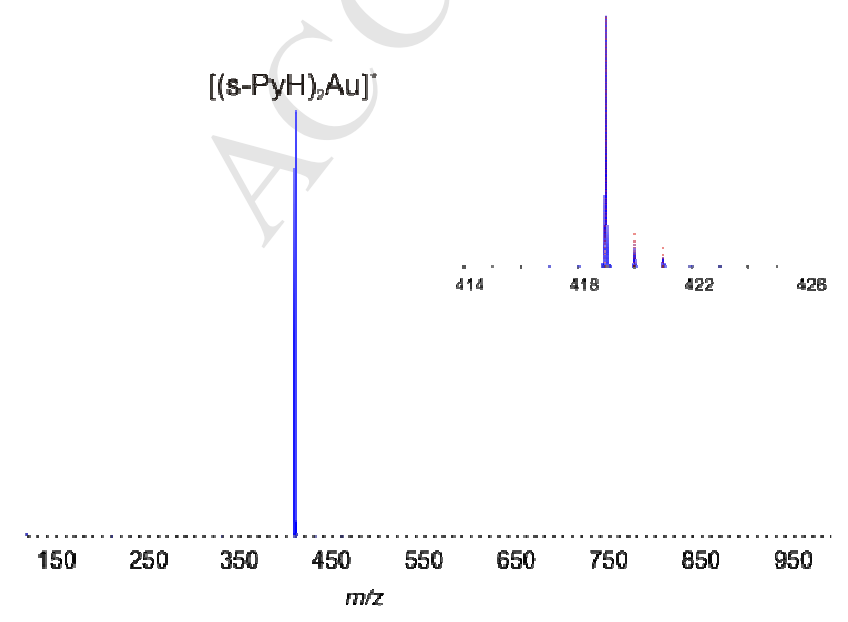


Figure 6. The ESI-QTOF MS spectrum of 3 in $\mathrm{MeOH}$. Inset showing the comparison between experimental and calculated (red dotted lines) isotopic distribution for the $\left[(\mathrm{S}-\mathrm{PyH})_{2} \mathrm{Au}\right]^{+}\left(\mathrm{C}_{10} \mathrm{H}_{10} \mathrm{AuN}_{2} \mathrm{~S}_{2}^{+}\right)$ion.

\section{Computational results}

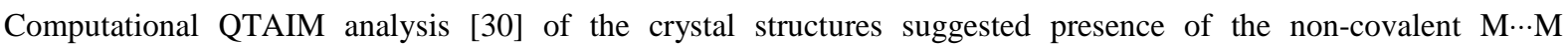
interactions only in $\mathrm{Cu}(\mathrm{I})(\mathbf{1})$ and $\mathrm{Au}(\mathrm{I})(\mathbf{3})$ polymers. The computational results are summarized in Table 3.

Table 3. Values of the density of all electrons $-\rho(\mathbf{r})$, Laplacian of electron density $-\nabla^{2} \rho(\mathbf{r})$, energy density $-H_{b}$, potential energy density $-\mathrm{V}(\mathbf{r})$, and Lagrangian kinetic energy - G(r) (Hartree) at the bond critical points $(3,-1)$ (BCPs), corresponding to the non-covalent $\mathrm{M} \cdots \mathrm{M}$ interactions in (1) and (3) as well as energies of these interactions $\mathrm{E}_{\text {int }}(\mathrm{kcal} / \mathrm{mol})$, defined by two approaches.

\begin{tabular}{|c|c|c|c|c|c|c|c|}
\hline Polymer & $\rho(\mathbf{r})$ & $\nabla^{2} \rho(\mathbf{r})$ & $\mathrm{H}_{\mathrm{b}}$ & $\mathrm{V}(\mathrm{r})$ & $\mathrm{G}(\mathrm{r})$ & $\mathrm{E}_{\text {int }}^{\mathrm{a}}$ & $\mathrm{E}_{\text {int }}^{\mathrm{b}}$ \\
\hline $\mathrm{Cu}(\mathrm{I})(\mathbf{1})$ & 0.034 & $0.034-0.038$ & -0.012 & $-0.033--0.034$ & $0.021-0.022$ & $10.35-10.67$ & $5.65-5.92$ \\
\hline $\mathrm{Au}(\mathrm{I})(\mathbf{3})$ & 0.016 & 0.044 & 0.000 & -0.011 & 0.011 & 3.45 & 2.96 \\
\hline
\end{tabular}

The QTAIM analysis of $(\mathbf{1})$ confirmed the presence of nine bond critical points (BCPs) $(3,-1)$ for $\mathrm{Cu} \cdots \mathrm{Cu}$ contacts in the copper polymer and the presence of four BCPs for $\mathrm{Au} \cdots \mathrm{Au}$ contacts in the gold chain (3), indicating attractive interactions between the metal centers. Surprisingly, no BCPs for Ag ..Ag contacts could be found in Ag(I) polymer (2). In the case of $\mathbf{3}$, low electron density, positive value of the Laplacian, and zero energy density at BCPs indicate typical non-covalent interactions, whereas in $1, \mathrm{Cu} \cdots \mathrm{Cu}$ metallophilic interactions already posses a noticeable degree covalent component (relatively high $\rho(\mathbf{r})$, noticeably negative $\mathrm{H}_{\mathrm{b}}$ value, $-\mathrm{G}(\mathbf{r}) / \mathrm{V}(\mathbf{r})<1$ at the appropriate $\left.\mathrm{BCP}\right)$. We also estimated the interactions energies of the metal-metal contacts according to the procedures proposed by Espinosa et al. [34] and Vener et al. [35] The energies are in line with the QTAIM parameters indicating weak interactions in gold polymers $(3.0-3.5 \mathrm{kcal} / \mathrm{mol})$ and relatively stronger contacts in copper polymer $(5.7-10.7 \mathrm{kcal} / \mathrm{mol})$.

\section{Summary}

The 4-pyridinethiol was found to support linear chain structures of $\mathrm{Cu}(\mathrm{I})$ and $\mathrm{Ag}(\mathrm{I})$ and to serve as useful bridging ligand bringing metal centers to close proximity. Owing the restricted coordination geometry of $\mathrm{Au}(\mathrm{I})$, 4-pyridinethiol does not favor bridging coordination with gold. Instead, the cationic gold(I) complexes were stacked together forming non-covalent metallopolymer with weak aurophilic contacts. According to the QTAIM analysis, metal-metal interactions appear only in the $\mathrm{Cu}(\mathrm{I})$ and $\mathrm{Au}(\mathrm{I})$ polymers. No bond critical points were observed in the $\mathrm{Ag}(\mathrm{I})$ polymer despite the fact that the $\mathrm{Ag} \cdots \mathrm{Ag}$ distance is shorter than the sum of Bondi's van der Waals radii. One of the main advantages of 4-pyridinethiol ligand is possibility to change its protonation level by removal of the NH hydrogen. This allows adjusting the charge of the ligand that can be used to compensate the positive charge of metal centers. This, in turn, allows design of neutral or charged metallopolymers.

\section{ACKNOWLEDGMENT}


Financial support provided by the Magnus Ehrnrooth foundation (K.M) and Academy of Finland (M.H project no 139571, E.K project no's 284562 and 278743) as well as COST Action CM1302 are gratefully acknowledged. A.S.N is grateful to Russian Foundation for Basic Research for support (project No. 16-33-60063).

\section{ASSOCIATED CONTENT}

Supporting Information. The CID spectra of 1, NMR spectra for $\mathbf{1}$ and 3, ATR-IR for $\mathbf{2}$ and crystallographic data for 1-3. CCDC reference numbers for 1 1406018, for 2 1406016, and for 3 1406017. This material is available free of charge via the Internet at http://pubs.acs.org.

\section{REFERENCES}

1. a) Eloi, J-C.; Chabanne, L.; Whittel, G. R.; Manners, I.; Materials Today; 2008, 22, 4, 28 b) Whittel, G. R.; Hager, M. D.; Schubert, U. S.; Manners, I.; Nature Mater.; 2011, 10, 176 c) Whittell, G.R.; Manners, I.; Adv. Mater.; 2007, 19, 3439

2. a) Chardon-Noblat, S.; Da Costa, P.; Deronizer, A.; Haukka, M.; Pakkanen, T. A.; Ziessel, R.; J. Electroanal. Chem.; 2000, 490, 62 b) Hastings, W. R.; Baird, M. C.; Inorg. Chem.; 1986, 25, 2913 c) Hirva, P.; Haukka, M.; Jakonen, M.; Pakkanen, T. A.; Inorg. Chim. Acta; 2006, 359, 853 d) Chardon-Noblat, S.; Deronizer, A.; Hartl, F.; Slageren, J. V.; Mahabiersing, T.; Eur. J. Inorg. Chem.; 2001, 613 e) Laurila, E.; Oresmaa, L.; Niskanen, M.; Hirva, P.; Haukka, M.; Cryst. Growth Des.; 2010, 10, 8, 3775 f) Laurila, E.; Tatikonda, R.; Hirva, P.; Haukka, M.; CrystEngComm.; 2012, 14, 8401 g) Laurila, E.; Oresmaa, L.; Hassinen, J.; Hirva, P.; Haukka, M.; Dalton Trans.; 2013, 42, 395 h) Koskinen, L.; Jääskeläinen, S.; Oresmaa, L.; Haukka, M.; CrystEngComm.; 2012, 14, 3509 i) Holliday, B. J.; Stanford, T. B.; Swager, T. M.; Chem. Mater.; 2006, 18, 5649

3. Knapton, D.; Rowan, S. J.; Weder, C.; Macromolecules; 2006, 39, 651

4. Choi, T.-L.; Lee, K-H.; Joo, W-J.; Lee, S.; Lee, T-W.; Chae, M. Y.; J. Am. Chem. Soc.; 2007, 129, 9842

5. Masciocchi, N.; Moret, M.; Cairati, P.; Ragaini, F.; Sironi, A.; J.Chem. Soc.Chem. Commun. .; 1994, 189

6. a) Zhou, Y.; Zhang, X.; Chen, W.; Qiu, H.; J. Organomet. Chem.; 2008, 693, 205 b) Jiao, Y-Q; Lu, G-W.; Zhao, K.; Chen, Y.; Lan, J-H.; Shao, C-J.; Wang, A-J.; Zhang, P.; Zhang, W-S.; Zhou, G-G.; Yang, Q.; Wang, M.; J. Mol. Struct. 2010, 957, 1 c) Che, C-M.; Lai, S-W,; Coord.Chem.Rev.; 2005, 249, 1296 d) Chen, C-T.; Suslick, K. S.; Coord. Chem. Rev.; 1993, 128, 293 e) Doerrer, L. H.; Dalton Trans.; 2010, 39, 3543 f) Ismayilov, R. H.; Wang, W-Z.; Lee, G-H.; Yeh, C-Y.; Hua, S-A.; Song, Y.; Rohmer, M-M.; Benard, M.; Peng, S-M.; Angew. Chem. Int. Ed.; 2011, 50, 2045 g) Sheu, J-T.; Lin, C-C.; Chao, I.; Wang, C-C.; Peng, S-M.; Chem.Comm.;1996, 3, 315 h)Yang, E-C.; Cheng, M-C.; Tsai, M-S.; Peng, S-M.; J. Chem. Soc., Chem. Commun.; 1994, 2377 7. a) Hartl, H. Angew. Chem. Int. Ed. 1987, 26, 927 b) Etaiw, S- E-D. H.; Abd El-Aziz, D. M.; Ibrahim, M. S.; Badr El-din; I. A. S.; Polyhedron; 2009, 1001 c) Dahl, L.F.; Wei, C. H.; inorg. Chem.; 1970, 9, 1878

8. a) Taylor, I.F.; Weininger, M. S.; Amma, E. L.; inorg. chem.; 1974, 13, 2835 b) Block, E.; Gernon, M.; Kang, H.; Ofori-Okai, G.; Zubieta, J.; Inorg. Chem.; 1991, 30, 1736 c) Isab, A. A.; Nawaz, S.; Saleem, M.; Altaf, M.; Monim-ul-mehboob, M.; Ahmad, S.;Evans, H. S.; Polyhedron; 2010, 29, 1251 d) Su,W.; Hong, M.; Weng, J.; Liang, Y.; Zhao, Y.; Cao, R.; Zhou, Z.; Chan, A. S. C.; Inorg. Chim. Acta; 2002, 331,8 e) Cheng, J-K.; Yao, Y-G.; Zhang, J.; Li, Z-J.; Cai, Z-W.; Zhang, X-Y.; Chen, Z-N.; Chen, Y-B.; Kang, Y.; Qin, Y-Y.; Wen, Y-H.; J. Am. Chem. Soc., 2004, 126, 25, 7796 f) Jalilian, E.; Lidin, S.; J. Solid State Chem., 2010, 183, 2656 g) Wang, H.; Zhong, R.; Guo, X-Q.; Feng, X-Y.; Hou, X-F.; Eur. J. Inorg. Chem.; 2010, 174 h) Han, Y-F.; Lin, Y-J.; Jia, WG.; Jin, G-X.; J. Organomet. Chem.; 2009, 2077 i) Qin, S.; Ke, Y.; Lu, S.; Li, J.; Pei, X.; Wu, X.; Du, W.; J. Mol. Struct.; 2004, 689, 75

9. Hao, Z-M.; Liu, H-P.; Han, H-H.; Wang, W-T.; Zhang, X-M.; Inorg. Chem. Comm.; 2009, 12, 375

10. Anjali, K.S; Vittal, J. J.; Dean, P. A. W.; Inorg. Chim. Acta; 2003, 351, 79

11. Wang, H.; Zhong, R.; Guo, X-G.; Feng, X-Y.; Hou, X-F.; Eur. J. Inorg. Chem.; 2010, 174

12. Neo, K.E.; Huynh, H. V.; Koh, L. L.; Henderson, W.; Hor, T. S. A.; Dalton Trans.; 2007, 5701

13. Wang, J.; Zhang, Y-H.; Li, H-X.; Lin, Z-J.; Tong, M-L.; Crys. Growth. Des.; 2007, 7, 11, 2352

14. a) Paw, W.; Lachicotte, R. J.; Eisenberg, R.; Inorg.Chem.; 1998, 37, 16, 4139 b) El-khateeb, M.; Shawakfeh, K.; Al-Btoosh, M.; Görls, H.; Weigand, W.; Polyhedron; 1997, 16, 3641 
15. Kharisov, B. I.; Martinez, P. E.; Jimenez-Perez, V. M.; Kharissova, O. V.; Martinez, B. N.M.;Perez, N.; J. Coord. Chem.; 2010, $63,1,1$

16. a) Bai, S-Q.; Jiang, L.; Zuo, J-L.; Hor, T. S. A.; Dalton Trans.; 2013, 42, 11319 b) Brown, D. H.; Smith, W. E.; Chem. Soc. Rev.; 1980, 9, 217 c) Hinnen, C.; Niki, K. J. Electroanal. Chem. 1989, 264,157 d) He, Y-K.; Han, Z-B.; Ma, Y.; Zhang, X-D.; Inorg.Chem.Commun.; 2007, 10, 829 e) Lago, A.B.; Carballo, R.; Fabelo, O.; Fernandez-Hermida, N.; Lloret, F.; Vazquez-Lopez, E. M.; CrystEngComm;. 2013, 15, 10550 f) Kole, G. K.; Vivekananda, K. V.; Kumar, M.; Ganguly, R.; Dey, S.; Jain, V. K.; CrystEngComm.; 2015, 17, 4367

17. a) El-Bahraoui, J.; J. Mol. Struct.; 1999, 493, 249 b) Alam, M. M.; Fromager, E.; Chem.Phys.Lett.; 2012, 554, 37 c) Hermann, H. L., Boche, G.; Schwerdtfeger, P.; Chem. Eur. J.; 2001, 7, 5333 d) Assadollahzadeh, B.; Schwerdtfeger, P.; Chem. Phys. Lett. 2008, 462, 222 e) Cotton, F.A.; Feng, X.; Timmons, D. J.; Inorg. Chem.; 1998, 37, 4066 f) Harwell, D.E, Mortimer, M. D.; Knobler, C. B.; Anet, F. A. L.; Hawthorne, M. F.; J. Am. Chem. Soc.; 1996, 118, 2679 g) Harvey, P.D.; Coord. Chem. Rev.; 1996, 153,175

18. Alam, M.M.; Fromager, E.; Chem.Phys.Lett.; 2012, 554, 37

19. Che, C-M.; Lai, S-W.; Coord. Chem. Rev.; 2005, 249, 1296

20. Agilent, CrysAlisPro, Agilent Technologies inc., 2013, Yarnton, Oxfordshire, England.

21. Otwinowski, Z.; Minor, W. Processing of X-ray Diffraction Data Collected in Oscillation Mode, Academic Press, New York, pp. 307-326, 1997. In Methods in Enzymology, Volume 276, Macromolecular Crystallography, Part A, Carter, C. W., Sweet, J., Eds.; Academic Press: New York, USA, 1997; pp 307-326.

22. Palatinus, L.; Chapuis, G.; J. Appl. Cryst.; 2007, 40, 786-790.

23. Sheldrick, G. M.; Acta Cryst.; 2008, A64, 112-122.

24. Sheldrick, G. M. SADABS - Bruker AXS scaling and absorption correction -, Bruker AXS, Inc., Madison, Wisconsin, USA, 2012.

25. Dolomanov, O. V.; Bourhis, L. J.; Gildea, R. J.; Howard, J. A. K.; Puschmann, H.; J. Appl. Cryst.; 2009, 42, 339-341.

26. Hübschle, C. B.; Sheldrick, G. M.; Dittrich, B.; J. Appl. Cryst;. 2011, 44, 1281-1284.

27. Zhao, Y.; Truhlar, D. G.; Theor. Chem. Acc..; 2008, 120, 215

28.Gaussian 09, Revision D.01, M. J. Frisch, G. W. Trucks, H. B. Schlegel, G. E. Scuseria, M. A. Robb, J. R. Cheeseman, G. Scalmani, V. Barone, B. Mennucci, G. A. Petersson, H. Nakatsuji, M. Caricato, X. Li, H. P. Hratchian, A. F. Izmaylov, J. Bloino, G. Zheng, J. L. Sonnenberg, M. Hada, M. Ehara, K. Toyota, R. Fukuda, J. Hasegawa, M. Ishida, T. Nakajima, Y. Honda, O. Kitao, H. Nakai, T. Vreven, J. A. Montgomery, Jr., J. E. Peralta, F. Ogliaro, M. Bearpark, J. J. Heyd, E. Brothers, K. N. Kudin, V. N. Staroverov, T. Keith, R. Kobayashi, J. Normand, K. Raghavachari, A. Rendell, J. C. Burant, S. S. Iyengar, J. Tomasi, M. Cossi, N. Rega, J. M. Millam, M. Klene, J. E. Knox, J. B. Cross, V. Bakken, C. Adamo, J. Jaramillo, R. Gomperts, R. E. Stratmann, O. Yazyev, A. J. Austin, R. Cammi, C. Pomelli, J. W. Ochterski, R. L. Martin, K. Morokuma, V. G. Zakrzewski, G. A. Voth, P. Salvador, J. J. Dannenberg, S. Dapprich, A. D. Daniels, O. Farkas, J. B. Foresman, J. V. Ortiz, J. Cioslowski, and D. J. Fox, Gaussian, Inc., Wallingford CT, 2013.

29. a) Barros, C. L.; de Oliveira, P. J. P.; Jorge, F. E.; Canal Neto, A.; Campos, M.; Mol. Phys.; 2010, 108, 1965 b) Jorge, F. E.; Canal Neto, A.; Camiletti, G. G.; Machado, S. F.; J. Chem. Phys.; 2009, 130, 064108 c) Canal Neto, A.; Jorge, F. E.; Chem. Phys. Lett, 2013, 582, 158.

30. Bader, R. F. W. Atoms in Molecules: A Quantum Theory, Oxford University Press, Oxford 1990.

31. Lu, T.; Chen, F. W. ; J. Comput. Chem.; 2012, 33, 580.

32. Bianketti, S.; Blake, A. J.; Wilson, C.; Hubberstey, P.; Champess, N. R.; Schröder, M.; CrystEngComm,; 2009, 11, 763

33. Räisänen, M. T.; Runeberg, N.; Klinga, M.; Nieger, M.; Bolte, M.; Pyykkö, P.;Leskelä, M.; Repo, T.; Inorg. Chem., 2007, 46 , 9954

34. Espinosa, E.; Molins, E.; Lecomte, C.; Chem. Phys. Lett.; 1998, 285, 170.

35. Vener, M. V.; Egorova, A. N.; Churakov, A. V.; Tsirelson, V. G.; J. Comput. Chem.; 2012, 33, 2303. 


\section{Graphical Abstract}

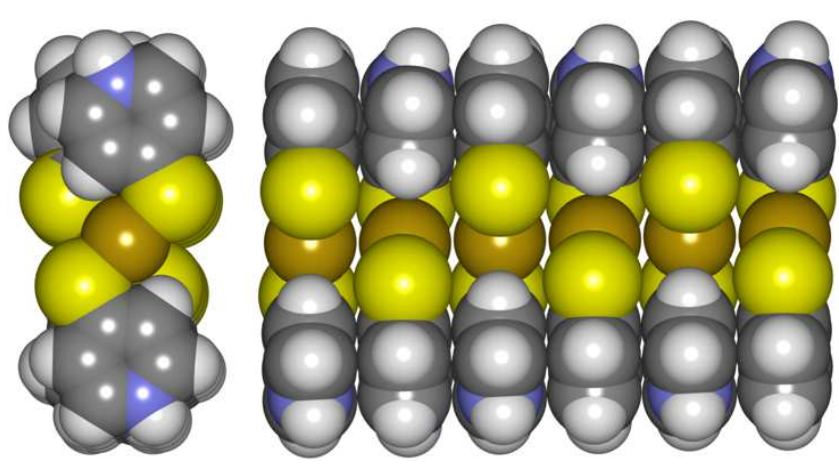




\section{Electronic Supporting Information}

\section{Metallophilic interactions in polymeric group 11 thiols}

Kalle Kolari ${ }^{\mathrm{a}}$, Joona Sahamies ${ }^{\mathrm{a}}$, Elina Kalenius ${ }^{\mathrm{a}}$, Alexander S. Novikov ${ }^{\mathrm{b}}$, Vadim Yu. Kukushkin ${ }^{\mathrm{b}}$ and Matti Haukka ${ }^{\mathrm{a} *}$

${ }^{a}$ University of Jyvaskyla, Chemistry department. P. O. Box 35, FI-40014, University of Jyvaskyla, Finland e-mail: matti.o.haukka@jyu.fi

${ }^{b}$ Institute of Chemistry, Saint Petersburg State University, Universitetskaya Nab. 7/9, 199034 Saint Petersburg, Russian Federation

\section{Table of Contents}

${ }^{1} \mathrm{H} \mathrm{NMR}$-spectra of the crude product of $\left[\mathrm{Au}(\mathrm{S}-\mathrm{pyH})_{2}\right]_{n} \mathrm{Cl}(\mathbf{3}), \quad S 2$

${ }^{1} \mathrm{H} \mathrm{NMR}$-spectra of the crude product of $\left[\mathrm{Cu}_{2}(\mathrm{~S}-\mathrm{py})_{4}\right]_{n}\left[\mathrm{ZnCl} l_{4}\right]_{n}(\mathbf{1}) \quad S 3$

CID MS spectra of the isolated ion $\left[(S-p y)_{4} C u_{4}+C u\right]^{+}-S 4$

ATR-IR spectrum of product $[\operatorname{Ag}(\mathrm{S}-\mathrm{py})(\mathrm{S}-\mathrm{pyH})]_{\mathrm{n}}(\mathbf{2}) \quad S 5$

Cartesian atomic coordinates of the used model structures $\quad$ S6

$\begin{array}{ll}\text { Selected bond lengths and angles for } \mathbf{1 - 3} & S 20\end{array}$

$\begin{array}{ll}\text { Hydrogen bonds for 1-3 } & S 21\end{array}$ 


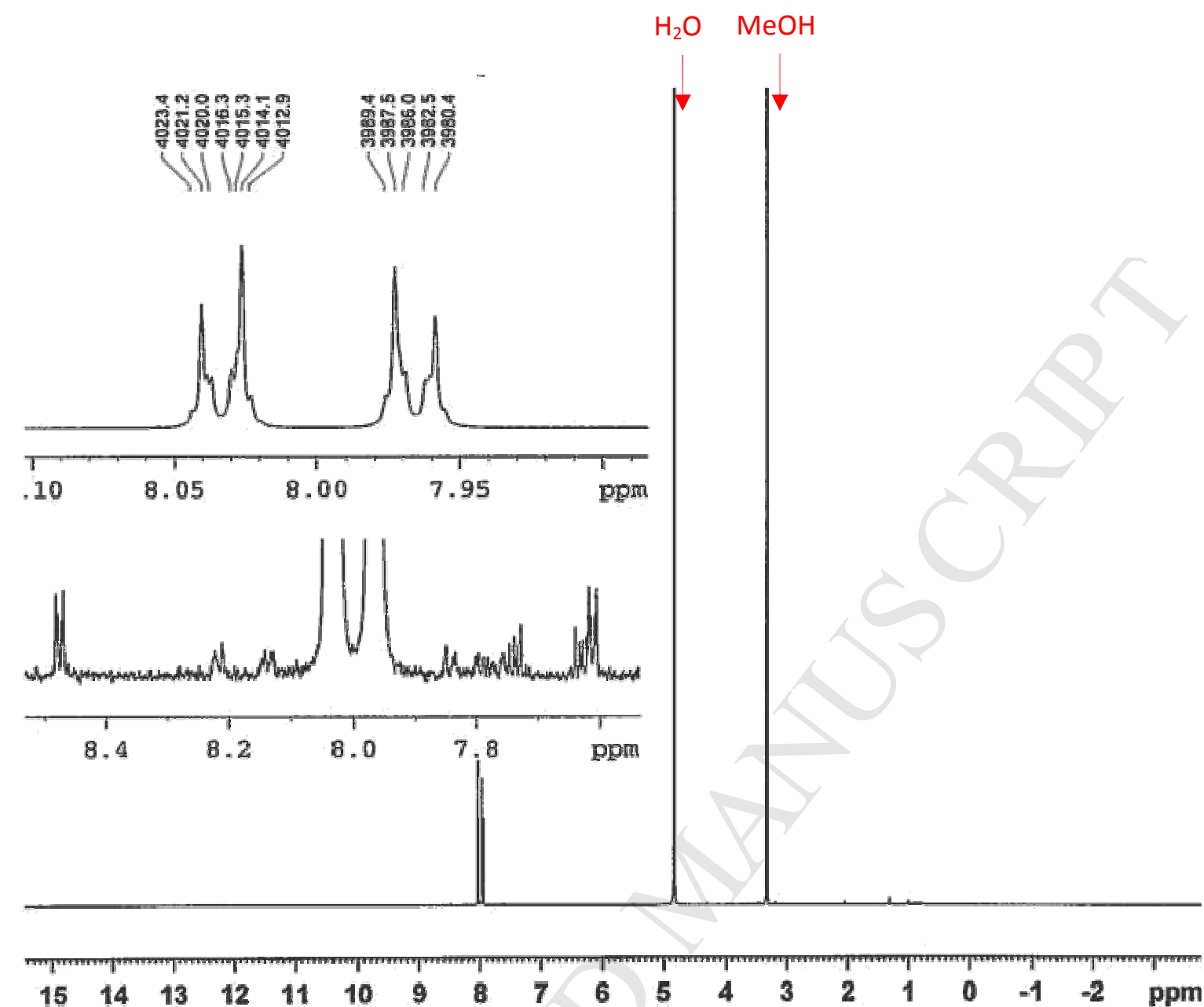

Figure S1. ${ }^{1} \mathrm{H}$ NMR-spectrum of the crude product of $\left[\mathrm{Au}(\mathrm{s}-\mathrm{pyH})_{2}\right]_{\mathrm{n}} \mathrm{Cl}(\mathbf{3})$. The crude product contained impurities of which 4-mercaptopyridine (S-Py) and 4,4'-dipyridylsulfide (dpds) were the most dominant ones. 


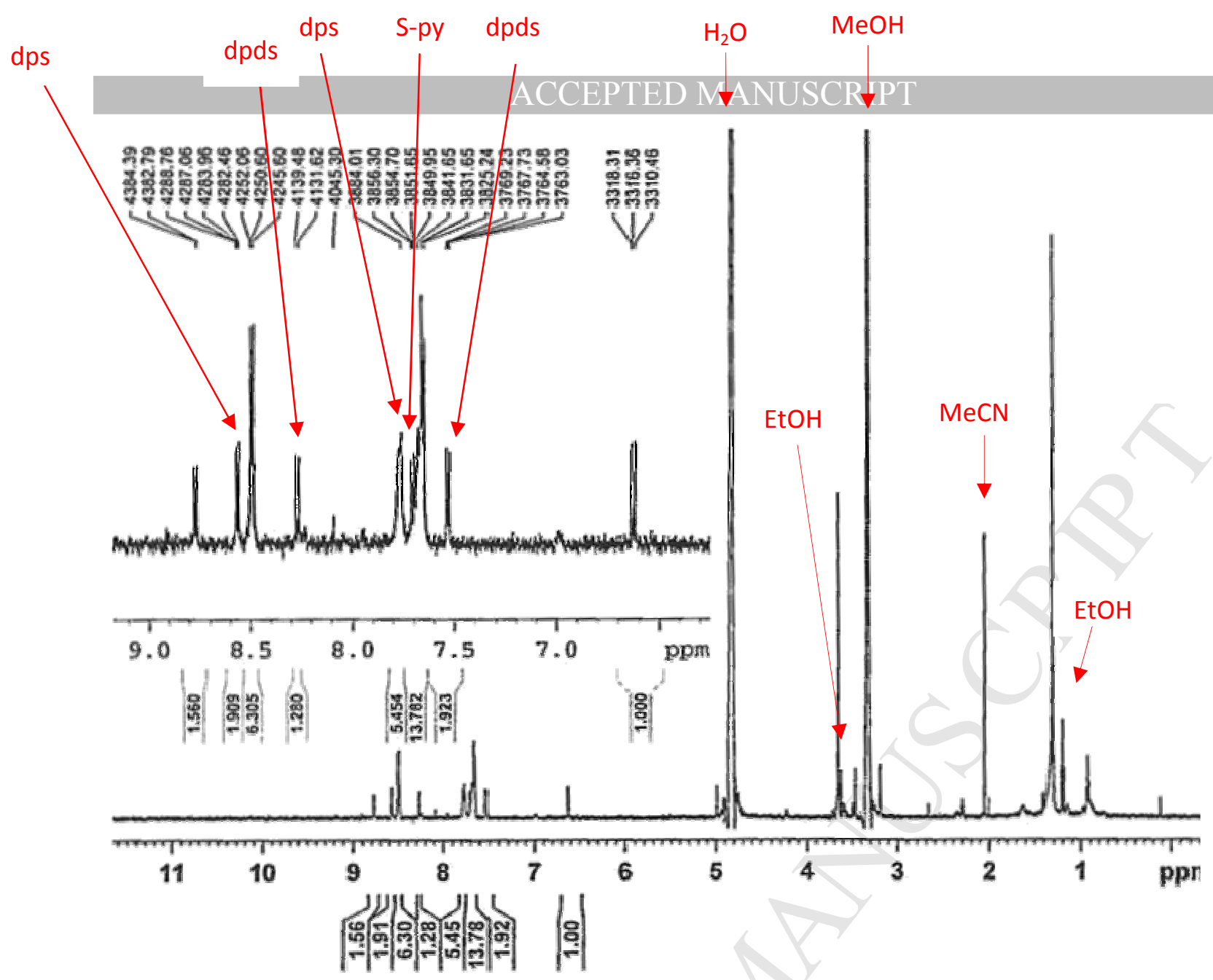

Figure S2. ${ }^{l} H$ NMR-spectrum of the crude product of $\left[\mathrm{Cu}_{2}(s-p y H)_{4}\right]_{n}{ }^{2+}(\mathbf{1})$. The crude product contained impurities of which 4-mercaptopyridine (S-Py) , 4,4'-dipyridylsulfide (dpds), and 4,4'dipyridylsulfide (dps) were the most dominant ones. 

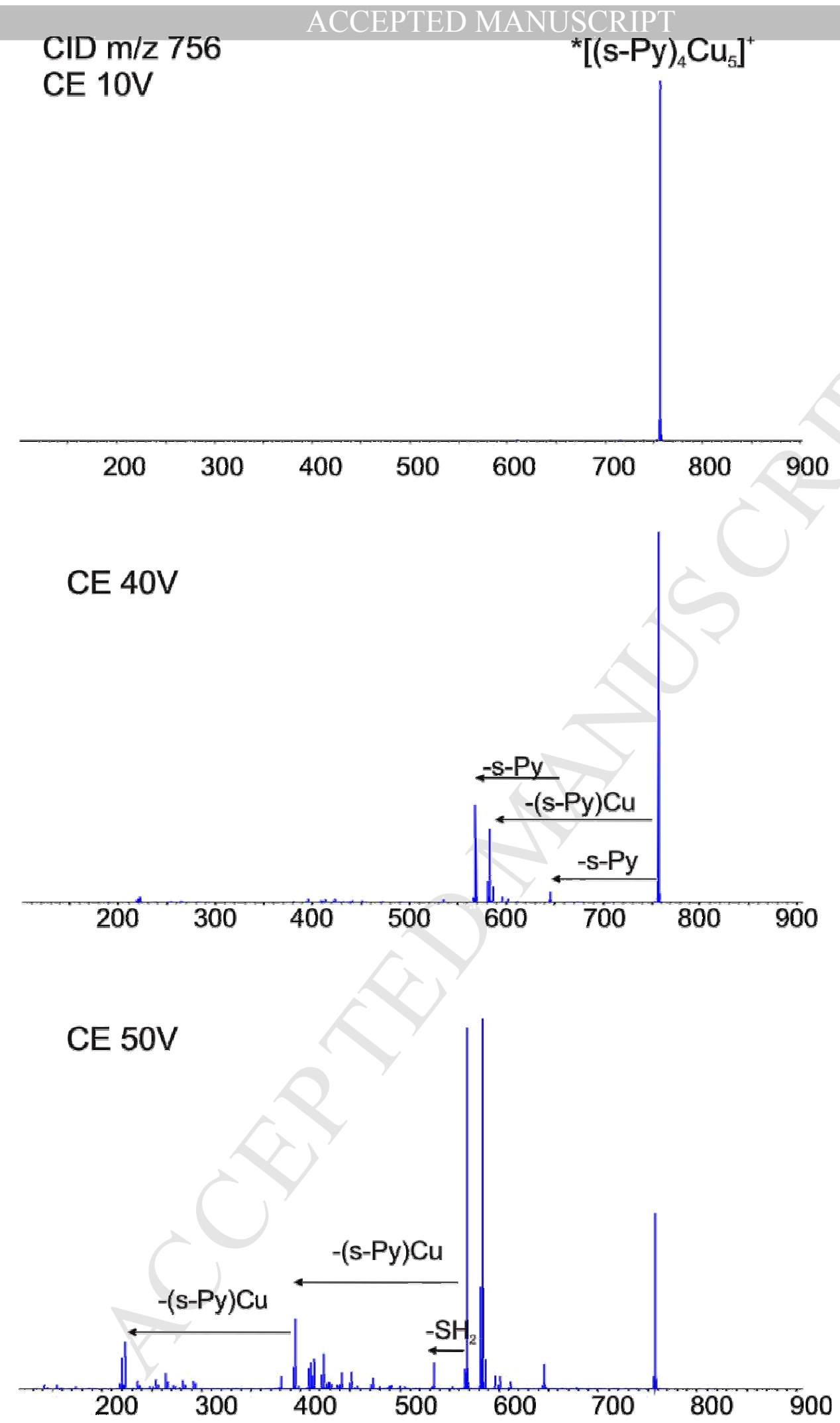

Figure S3. CID MS spectra of the isolated $\left[(s-\mathrm{Py}){ }_{4} \mathrm{Cu} u_{4}+\mathrm{Cu}\right]^{+}$ion measured at $\mathrm{CE}$ voltages 10

$V($ up), $40 \mathrm{~V}$ (middle) and $50 \mathrm{~V}$ (down). 


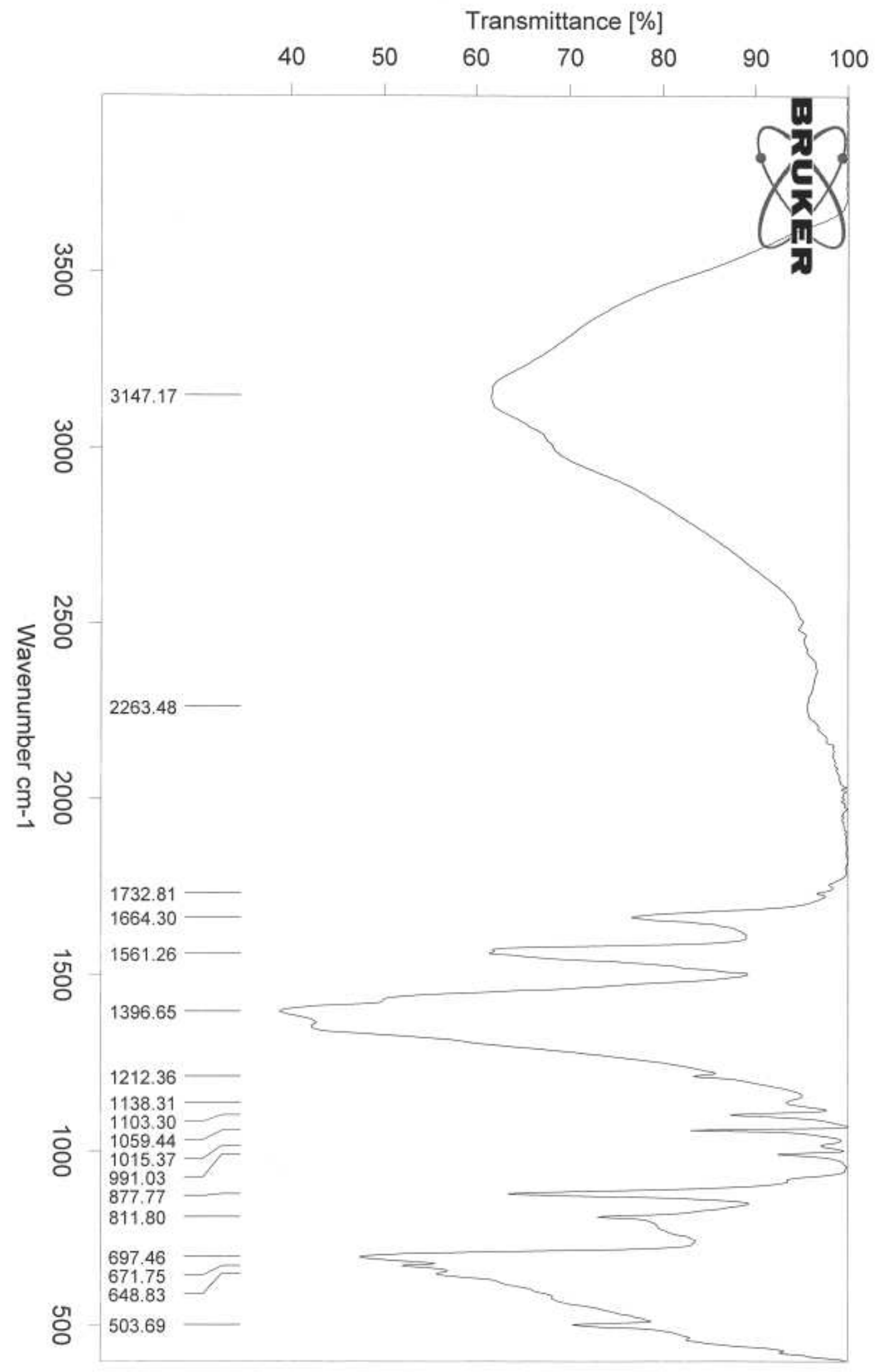

Figure S4. ATR-IR spectrum of product $[\mathrm{Ag}(\mathrm{S}-\mathrm{py})(\mathrm{S}-\mathrm{pyH})]_{\mathrm{n}}$ (2) 
Table S1. Cartesian atomic coordinates of the used model structures.

\begin{tabular}{|c|c|c|c|}
\hline Atom & $\mathrm{X}$ & $\mathrm{Y}$ & $\mathrm{Z}$ \\
\hline \multicolumn{4}{|c|}{ (1) } \\
\hline $\mathrm{Cu}$ & 2.130771 & 3.431856 & 6.998910 \\
\hline $\mathrm{Cu}$ & 1.350833 & 0.984651 & 7.556108 \\
\hline S & 3.821690 & 4.334318 & 8.259452 \\
\hline$S$ & 2.828999 & 1.546761 & 5.806827 \\
\hline S & 0.037733 & 2.849476 & 8.018059 \\
\hline $\mathrm{S}$ & 2.640493 & 0.044775 & 9.271160 \\
\hline $\mathrm{N}$ & 7.825730 & 4.954515 & 6.300924 \\
\hline $\mathrm{H}$ & 8.561156 & 5.041242 & 5.947020 \\
\hline $\mathrm{N}$ & 0.647560 & 1.798066 & 1.886795 \\
\hline $\mathrm{H}$ & 0.203879 & 1.843447 & 1.047723 \\
\hline $\mathrm{N}$ & 0.082281 & 3.516465 & 12.441416 \\
\hline $\mathrm{H}$ & -0.001747 & 3.620336 & 13.233459 \\
\hline $\mathrm{N}$ & 0.784606 & 0.109921 & 13.357280 \\
\hline $\mathrm{H}$ & 0.489995 & 0.107904 & 14.129381 \\
\hline $\mathrm{C}$ & 5.346974 & 4.553152 & 7.465028 \\
\hline $\mathrm{C}$ & 6.344046 & 5.317557 & 8.094555 \\
\hline $\mathrm{H}$ & 6.162551 & 5.721945 & 8.935412 \\
\hline $\mathrm{C}$ & 7.573210 & 5.488993 & 7.514735 \\
\hline $\mathrm{H}$ & 8.246567 & 5.983134 & 7.965078 \\
\hline $\mathrm{C}$ & 6.909815 & 4.200194 & 5.659789 \\
\hline $\mathrm{H}$ & 7.121621 & 3.817992 & 4.815955 \\
\hline $\mathrm{C}$ & 5.678932 & 3.979344 & 6.213713 \\
\hline $\mathrm{H}$ & 5.044242 & 3.439823 & 5.756525 \\
\hline $\mathrm{C}$ & 1.959898 & 1.664951 & 4.309655 \\
\hline $\mathrm{C}$ & 2.671217 & 1.678061 & 3.095248 \\
\hline $\mathrm{H}$ & 3.620209 & 1.640748 & 3.101499 \\
\hline $\mathrm{C}$ & 1.995335 & 1.745627 & 1.902868 \\
\hline $\mathrm{H}$ & 2.479167 & 1.755711 & 1.086418 \\
\hline $\mathrm{C}$ & -0.070653 & 1.808151 & 3.020538 \\
\hline $\mathrm{H}$ & -1.018571 & 1.857565 & 2.979463 \\
\hline $\mathrm{C}$ & 0.558737 & 1.745627 & 4.240303 \\
\hline $\mathrm{H}$ & 0.045406 & 1.758737 & 5.039192 \\
\hline $\mathrm{C}$ & 0.091121 & 3.138296 & 9.723586 \\
\hline $\mathrm{C}$ & -1.115511 & 3.300657 & 10.433776 \\
\hline $\mathrm{H}$ & -1.946046 & 3.290572 & 9.971230 \\
\hline $\mathrm{C}$ & -1.084571 & 3.474110 & 11.794923 \\
\hline $\mathrm{H}$ & -1.896520 & 3.562854 & 12.278006 \\
\hline $\mathrm{C}$ & 1.258110 & 3.410578 & 11.796411 \\
\hline $\mathrm{H}$ & 2.072413 & 3.463017 & 12.283959 \\
\hline $\mathrm{C}$ & 1.285293 & 3.228048 & 10.446277 \\
\hline $\mathrm{H}$ & 2.118467 & 3.161491 & 9.995041 \\
\hline $\mathrm{C}$ & 1.899702 & 0.067566 & 10.838280 \\
\hline $\mathrm{C}$ & 0.506281 & 0.069583 & 11.021334 \\
\hline $\mathrm{H}$ & -0.067993 & 0.059499 & 10.265902 \\
\hline $\mathrm{C}$ & -0.030983 & 0.086727 & 12.283662 \\
\hline
\end{tabular}


ACCEPTED MANUSCRIPT

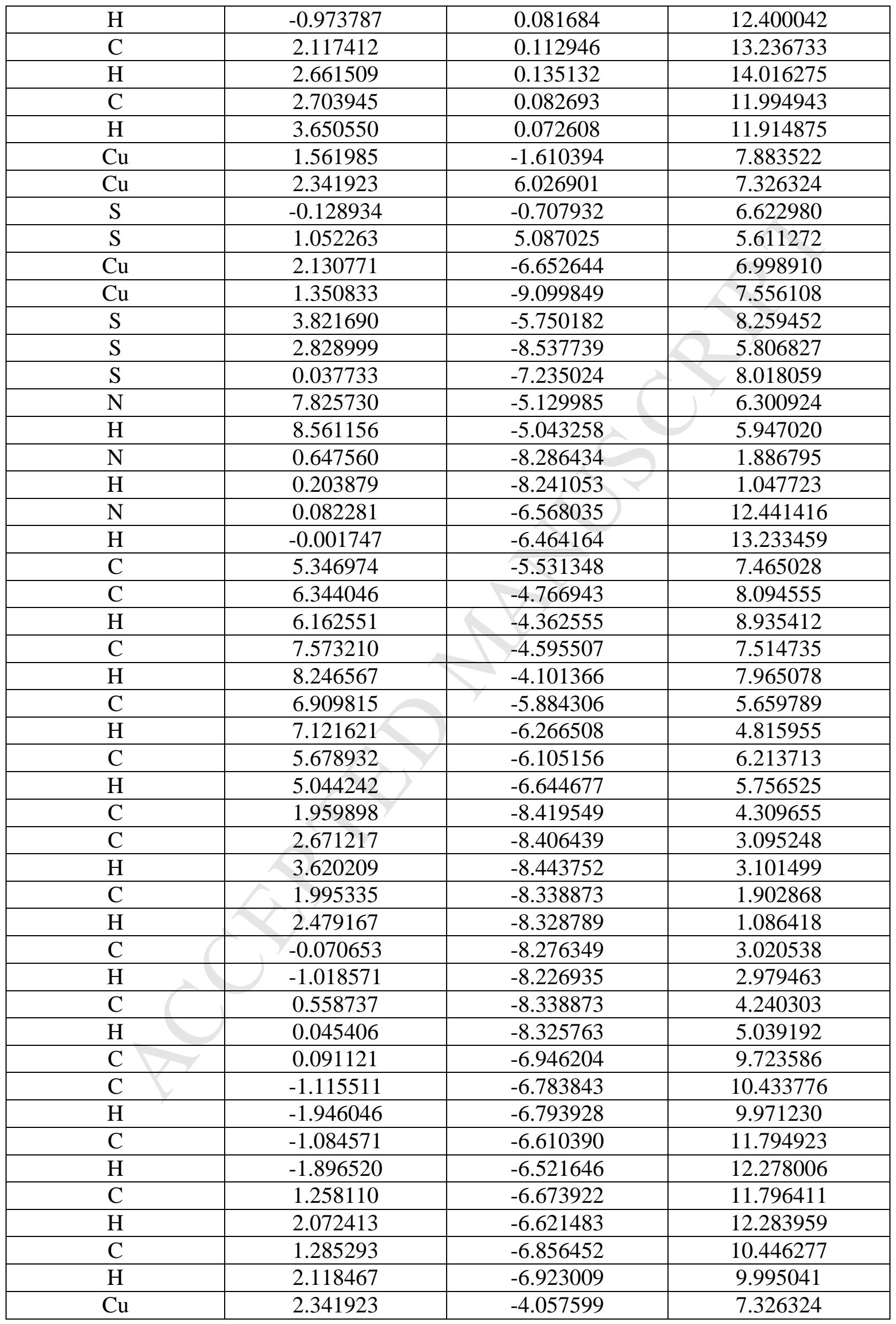


ACCEPTED MANUSCRIPT

\begin{tabular}{|c|c|c|c|}
\hline $\mathrm{S}$ & 1.052263 & -4.997475 & 5.611272 \\
\hline $\mathrm{S}$ & 0.863758 & -3.495489 & 9.075605 \\
\hline $\mathrm{S}$ & 3.655023 & -2.192774 & 6.864373 \\
\hline $\mathrm{N}$ & -4.132974 & -0.087735 & 8.581508 \\
\hline $\mathrm{H}$ & -4.868400 & -0.001008 & 8.935412 \\
\hline $\mathrm{N}$ & 3.045197 & -3.244184 & 12.995637 \\
\hline $\mathrm{H}$ & 3.488878 & -3.198803 & 13.834709 \\
\hline $\mathrm{N}$ & 3.610476 & -1.525785 & 2.441017 \\
\hline $\mathrm{H}$ & 3.694504 & -1.421915 & 1.648973 \\
\hline $\mathrm{N}$ & 2.908150 & -4.932329 & 1.525152 \\
\hline $\mathrm{H}$ & 3.202761 & -4.934346 & 0.753051 \\
\hline $\mathrm{C}$ & -1.654217 & -0.489098 & 7.417404 \\
\hline $\mathrm{C}$ & -2.651289 & 0.275307 & 6.787877 \\
\hline $\mathrm{H}$ & -2.469795 & 0.679695 & 5.947020 \\
\hline $\mathrm{C}$ & -3.880454 & 0.446743 & 7.367697 \\
\hline $\mathrm{H}$ & -4.553811 & 0.940884 & 6.917354 \\
\hline $\mathrm{C}$ & -3.217058 & -0.842056 & 9.222643 \\
\hline $\mathrm{H}$ & -3.428864 & -1.224258 & 10.066477 \\
\hline $\mathrm{C}$ & -1.986176 & -1.062906 & 8.668719 \\
\hline $\mathrm{H}$ & -1.351486 & -1.602427 & 9.125907 \\
\hline $\mathrm{C}$ & 1.732859 & -3.377299 & 10.572777 \\
\hline $\mathrm{C}$ & 1.021540 & -3.364189 & 11.787184 \\
\hline $\mathrm{H}$ & 0.072547 & -3.401502 & 11.780933 \\
\hline $\mathrm{C}$ & 1.697422 & -3.296623 & 12.979564 \\
\hline $\mathrm{H}$ & 1.213589 & -3.286539 & 13.796015 \\
\hline $\mathrm{C}$ & 3.763409 & -3.234099 & 11.861894 \\
\hline $\mathrm{H}$ & 4.711327 & -3.184685 & 11.902969 \\
\hline $\mathrm{C}$ & 3.134019 & -3.296623 & 10.642130 \\
\hline $\mathrm{H}$ & 3.647350 & -3.283513 & 9.843241 \\
\hline $\mathrm{C}$ & 3.601635 & -1.903954 & 5.158846 \\
\hline $\mathrm{C}$ & 4.808267 & -1.741593 & 4.448657 \\
\hline $\mathrm{H}$ & 5.638803 & -1.751678 & 4.911203 \\
\hline $\mathrm{C}$ & 4.777327 & -1.568140 & 3.087509 \\
\hline $\mathrm{H}$ & 5.589276 & -1.479396 & 2.604426 \\
\hline $\mathrm{C}$ & 2.434646 & -1.631672 & 3.086021 \\
\hline $\mathrm{H}$ & 1.620343 & -1.579233 & 2.598473 \\
\hline $\mathrm{C}$ & 2.407463 & -1.814202 & 4.436155 \\
\hline & 1.574290 & -1.880759 & 4.887391 \\
\hline & 1.793055 & -4.974684 & 4.044152 \\
\hline $\mathrm{C}$ & 3.186475 & -4.972667 & 3.861098 \\
\hline $\mathrm{H}$ & 3.760749 & -4.982751 & 4.616530 \\
\hline $\mathrm{C}$ & 3.723740 & -4.955523 & 2.598770 \\
\hline $\mathrm{H}$ & 4.666543 & -4.960566 & 2.482390 \\
\hline $\mathrm{C}$ & 1.575344 & -4.929304 & 1.645699 \\
\hline $\mathrm{H}$ & 1.031247 & -4.907118 & 0.866158 \\
\hline $\mathrm{C}$ & 0.988812 & -4.959557 & 2.887489 \\
\hline $\mathrm{H}$ & 0.042206 & -4.969642 & 2.967557 \\
\hline $\mathrm{Cu}$ & 2.130771 & 13.516356 & 6.998910 \\
\hline
\end{tabular}


ACCEPTED MANUSCRIPT

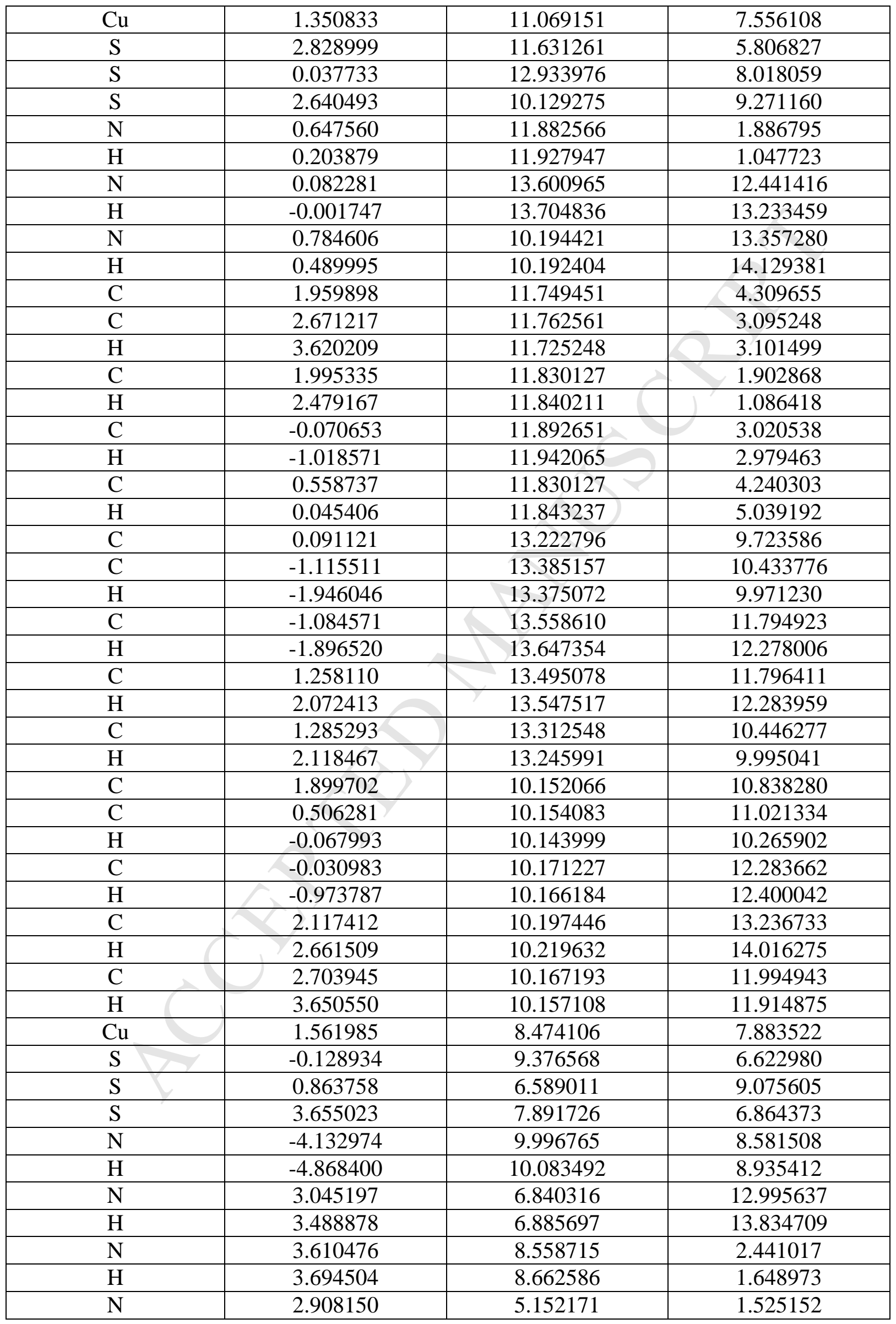


ACCEPTED MANUSCRIPT

\begin{tabular}{|c|c|c|c|}
\hline $\mathrm{H}$ & 3.202761 & 5.150154 & 0.753051 \\
\hline $\mathrm{C}$ & -1.654217 & 9.595402 & 7.417404 \\
\hline $\mathrm{C}$ & -2.651289 & 10.359807 & 6.787877 \\
\hline $\mathrm{H}$ & -2.469795 & 10.764195 & 5.947020 \\
\hline $\mathrm{C}$ & -3.880454 & 10.531243 & 7.367697 \\
\hline $\mathrm{H}$ & -4.553811 & 11.025384 & 6.917354 \\
\hline $\mathrm{C}$ & -3.217058 & 9.242444 & 9.222643 \\
\hline $\mathrm{H}$ & -3.428864 & 8.860242 & 10.066477 \\
\hline $\mathrm{C}$ & -1.986176 & 9.021594 & 8.668719 \\
\hline $\mathrm{H}$ & -1.351486 & 8.482073 & 9.125907 \\
\hline $\mathrm{C}$ & 1.732859 & 6.707201 & 10.572777 \\
\hline $\mathrm{C}$ & 1.021540 & 6.720311 & 11.787184 \\
\hline $\mathrm{H}$ & 0.072547 & 6.682998 & 11.780933 \\
\hline $\mathrm{C}$ & 1.697422 & 6.787877 & 12.979564 \\
\hline $\mathrm{H}$ & 1.213589 & 6.797961 & 13.796015 \\
\hline $\mathrm{C}$ & 3.763409 & 6.850401 & 11.861894 \\
\hline $\mathrm{H}$ & 4.711327 & 6.899815 & 11.902969 \\
\hline $\mathrm{C}$ & 3.134019 & 6.787877 & 10.642130 \\
\hline $\mathrm{H}$ & 3.647350 & 6.800987 & 9.843241 \\
\hline $\mathrm{C}$ & 3.601635 & 8.180546 & 5.158846 \\
\hline $\mathrm{C}$ & 4.808267 & 8.342907 & 4.448657 \\
\hline $\mathrm{H}$ & 5.638803 & 8.332822 & 4.911203 \\
\hline $\mathrm{C}$ & 4.777327 & 8.516360 & 3.087509 \\
\hline $\mathrm{H}$ & 5.589276 & 8.605104 & 2.604426 \\
\hline $\mathrm{C}$ & 2.434646 & 8.452828 & 3.086021 \\
\hline $\mathrm{H}$ & 1.620343 & 8.505267 & 2.598473 \\
\hline $\mathrm{C}$ & 2.407463 & 8.270298 & 4.436155 \\
\hline $\mathrm{H}$ & 1.574290 & 8.203741 & 4.887391 \\
\hline $\mathrm{C}$ & 1.793055 & 5.109816 & 4.044152 \\
\hline $\mathrm{C}$ & 3.186475 & 5.111833 & 3.861098 \\
\hline $\mathrm{H}$ & 3.760749 & 5.101749 & 4.616530 \\
\hline $\mathrm{C}$ & 3.723740 & 5.128977 & 2.598770 \\
\hline $\mathrm{H}$ & 4.666543 & 5.123934 & 2.482390 \\
\hline $\mathrm{C}$ & 1.575344 & 5.155196 & 1.645699 \\
\hline $\mathrm{H}$ & 1.031247 & 5.177382 & 0.866158 \\
\hline $\mathrm{C}$ & 0.988812 & 5.124943 & 2.887489 \\
\hline $\mathrm{H}$ & 0.042206 & 5.114858 & 2.967557 \\
\hline \multicolumn{4}{|c|}{ (2)_isotactic } \\
\hline & 6.081200 & 0.000000 & 1.596975 \\
\hline $\mathrm{S}$ & 4.393302 & 1.266235 & 3.193950 \\
\hline $\mathrm{N}$ & 5.662813 & 5.623467 & 3.193950 \\
\hline $\mathrm{C}$ & 4.895366 & 2.935613 & 3.193950 \\
\hline $\mathrm{C}$ & 3.947915 & 3.967186 & 3.193950 \\
\hline $\mathrm{C}$ & 4.365085 & 5.284573 & 3.193950 \\
\hline $\mathrm{C}$ & 6.584723 & 4.645113 & 3.193950 \\
\hline $\mathrm{C}$ & 6.239311 & 3.314767 & 3.193950 \\
\hline $\mathrm{H}$ & 3.019924 & 3.761203 & 3.193950 \\
\hline $\mathrm{H}$ & 3.710748 & 5.972702 & 3.193950 \\
\hline
\end{tabular}


ACCEPTED MANUSCRIPT

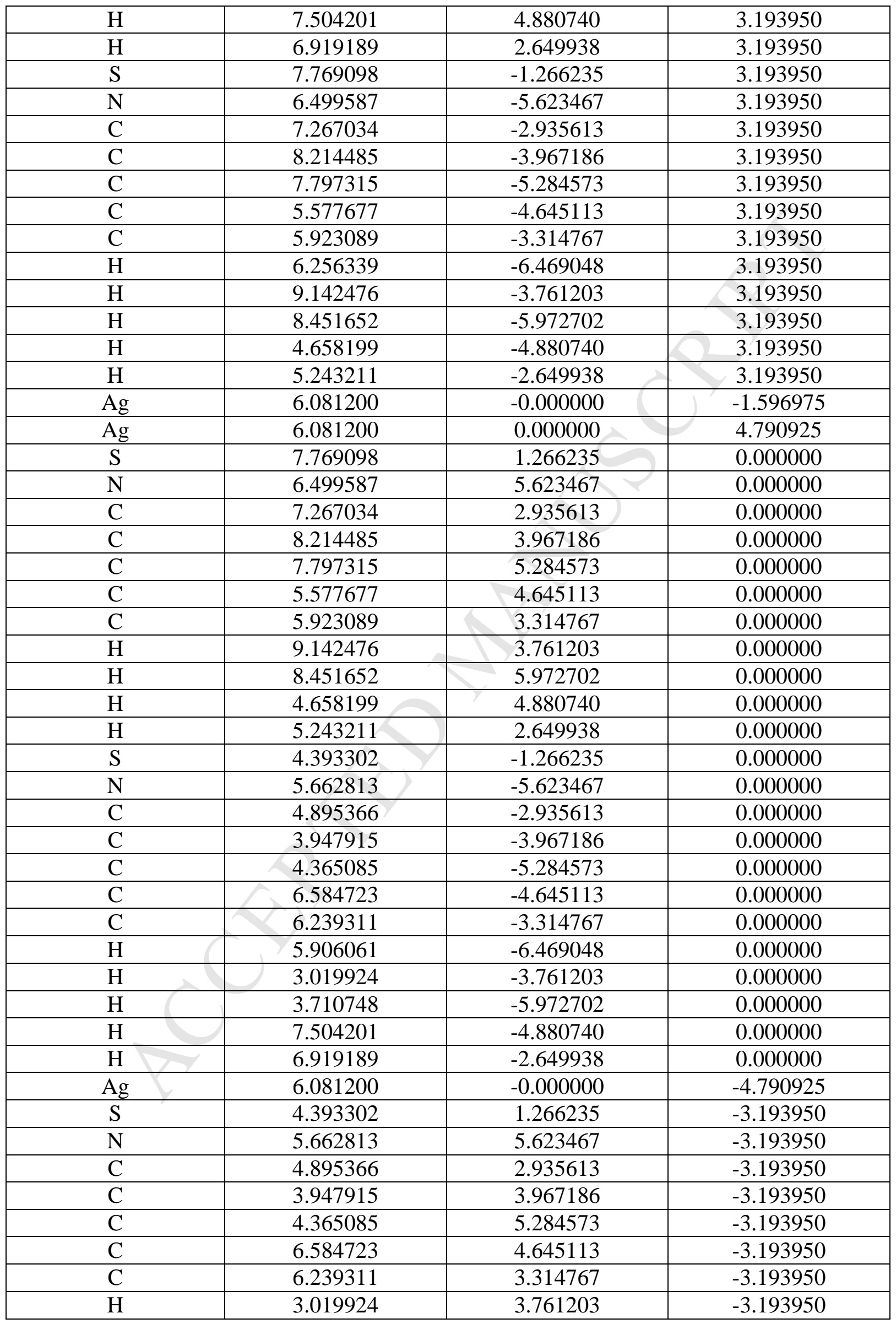


ACCEPTED MANUSCRIPT

\begin{tabular}{|c|c|c|c|}
\hline $\mathrm{H}$ & 3.710748 & 5.972702 & -3.193950 \\
\hline $\mathrm{H}$ & 7.504201 & 4.880740 & -3.193950 \\
\hline $\mathrm{H}$ & 6.919189 & 2.649938 & -3.193950 \\
\hline $\mathrm{S}$ & 7.769098 & -1.266235 & -3.193950 \\
\hline $\mathrm{N}$ & 6.499587 & -5.623467 & -3.193950 \\
\hline $\mathrm{C}$ & 7.267034 & -2.935613 & -3.193950 \\
\hline $\mathrm{C}$ & 8.214485 & -3.967186 & -3.193950 \\
\hline $\mathrm{C}$ & 7.797315 & -5.284573 & -3.193950 \\
\hline $\mathrm{C}$ & 5.577677 & -4.645113 & -3.193950 \\
\hline $\mathrm{C}$ & 5.923089 & -3.314767 & -3.193950 \\
\hline $\mathrm{H}$ & 6.256339 & -6.469048 & -3.193950 \\
\hline $\mathrm{H}$ & 9.142476 & -3.761203 & -3.193950 \\
\hline $\mathrm{H}$ & 8.451652 & -5.972702 & -3.193950 \\
\hline $\mathrm{H}$ & 4.658199 & -4.880740 & -3.193950 \\
\hline $\mathrm{H}$ & 5.243211 & -2.649938 & -3.193950 \\
\hline $\mathrm{Ag}$ & 6.081200 & -0.000000 & -7.984875 \\
\hline $\mathrm{S}$ & 7.769098 & 1.266235 & -6.387900 \\
\hline $\mathrm{N}$ & 6.499587 & 5.623467 & -6.387900 \\
\hline $\mathrm{C}$ & 7.267034 & 2.935613 & -6.387900 \\
\hline $\mathrm{C}$ & 8.214485 & 3.967186 & -6.387900 \\
\hline $\mathrm{C}$ & 7.797315 & 5.284573 & -6.387900 \\
\hline $\mathrm{C}$ & 5.577677 & 4.645113 & -6.387900 \\
\hline $\mathrm{C}$ & 5.923089 & 3.314767 & -6.387900 \\
\hline $\mathrm{H}$ & 9.142476 & 3.761203 & -6.387900 \\
\hline $\mathrm{H}$ & 8.451652 & 5.972702 & -6.387900 \\
\hline $\mathrm{H}$ & 4.658199 & 4.880740 & -6.387900 \\
\hline $\mathrm{H}$ & 5.243211 & 2.649938 & -6.387900 \\
\hline $\mathrm{S}$ & 4.393302 & -1.266235 & -6.387900 \\
\hline $\mathrm{N}$ & 5.662813 & -5.623467 & -6.387900 \\
\hline $\mathrm{C}$ & 4.895366 & -2.935613 & -6.387900 \\
\hline $\mathrm{C}$ & 3.947915 & -3.967186 & -6.387900 \\
\hline $\mathrm{C}$ & 4.365085 & -5.284573 & -6.387900 \\
\hline $\mathrm{C}$ & 6.584723 & -4.645113 & -6.387900 \\
\hline $\mathrm{C}$ & 6.239311 & -3.314767 & -6.387900 \\
\hline $\mathrm{H}$ & 5.906061 & -6.469048 & -6.387900 \\
\hline $\mathrm{H}$ & 3.019924 & -3.761203 & -6.387900 \\
\hline $\mathrm{H}$ & 3.710748 & -5.972702 & -6.387900 \\
\hline & 7.504201 & -4.880740 & -6.387900 \\
\hline $\mathrm{H}$ & 6.919189 & -2.649938 & -6.387900 \\
\hline $\mathrm{Ag}$ & 6.081200 & -0.000000 & -11.178825 \\
\hline $\mathrm{S}$ & 4.393302 & 1.266235 & -9.581850 \\
\hline $\mathrm{N}$ & 5.662813 & 5.623467 & -9.581850 \\
\hline $\mathrm{C}$ & 4.895366 & 2.935613 & -9.581850 \\
\hline $\mathrm{C}$ & 3.947915 & 3.967186 & -9.581850 \\
\hline $\mathrm{C}$ & 4.365085 & 5.284573 & -9.581850 \\
\hline $\mathrm{C}$ & 6.584723 & 4.645113 & -9.581850 \\
\hline $\mathrm{C}$ & 6.239311 & 3.314767 & -9.581850 \\
\hline $\mathrm{H}$ & 3.019924 & 3.761203 & -9.581850 \\
\hline
\end{tabular}


ACCEPTED MANUSCRIPT

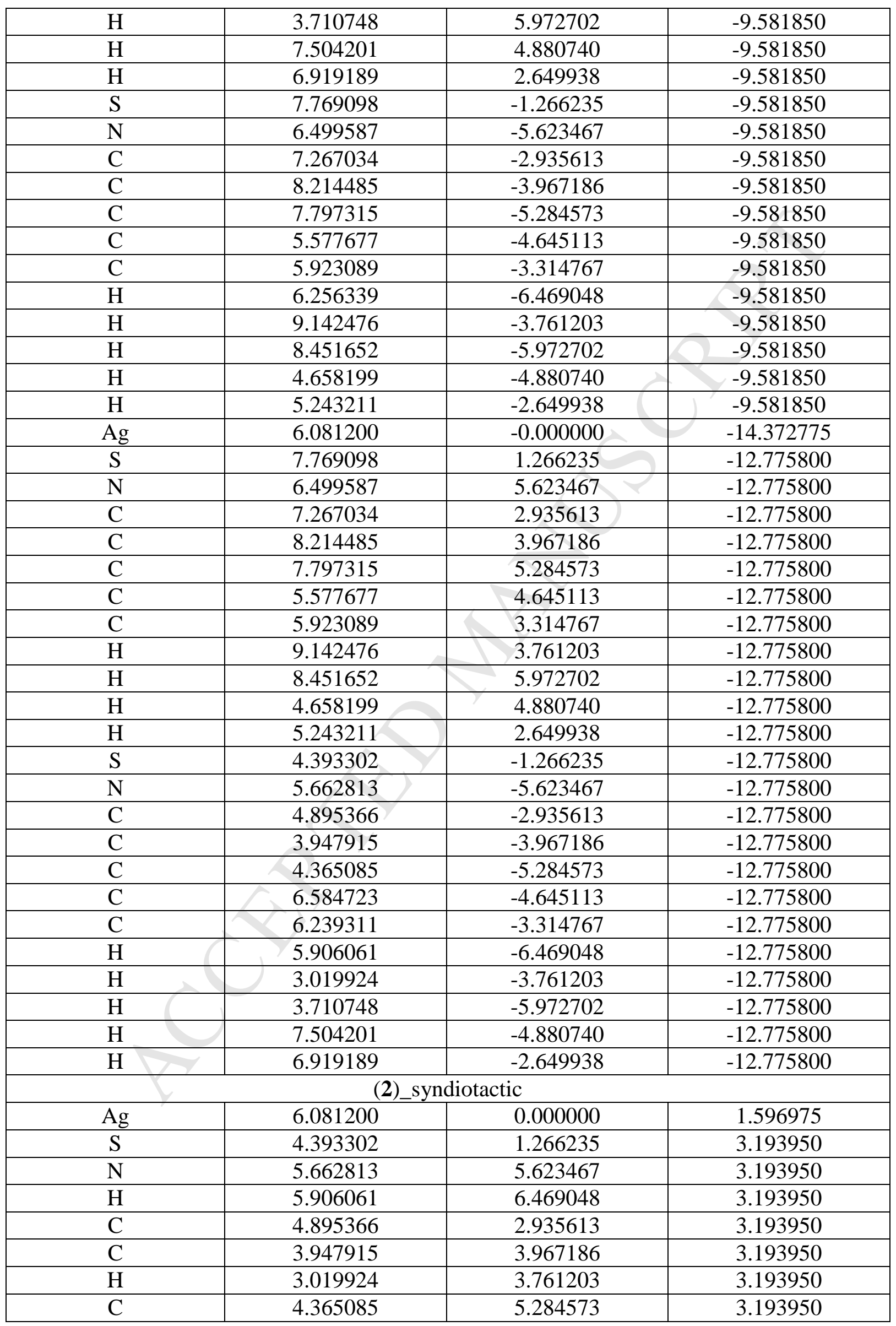


ACCEPTED MANUSCRIPT

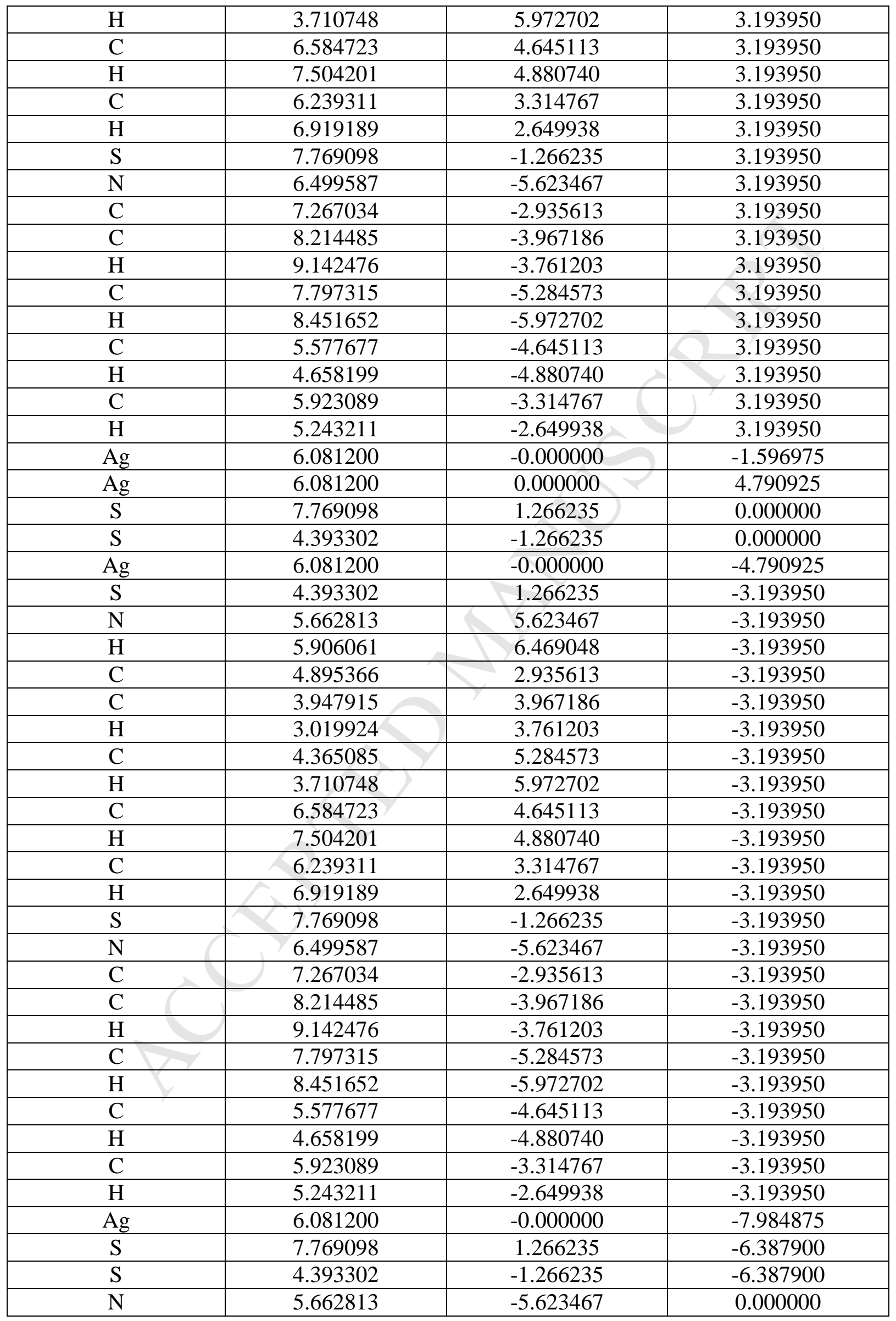


ACCEPTED MANUSCRIPT

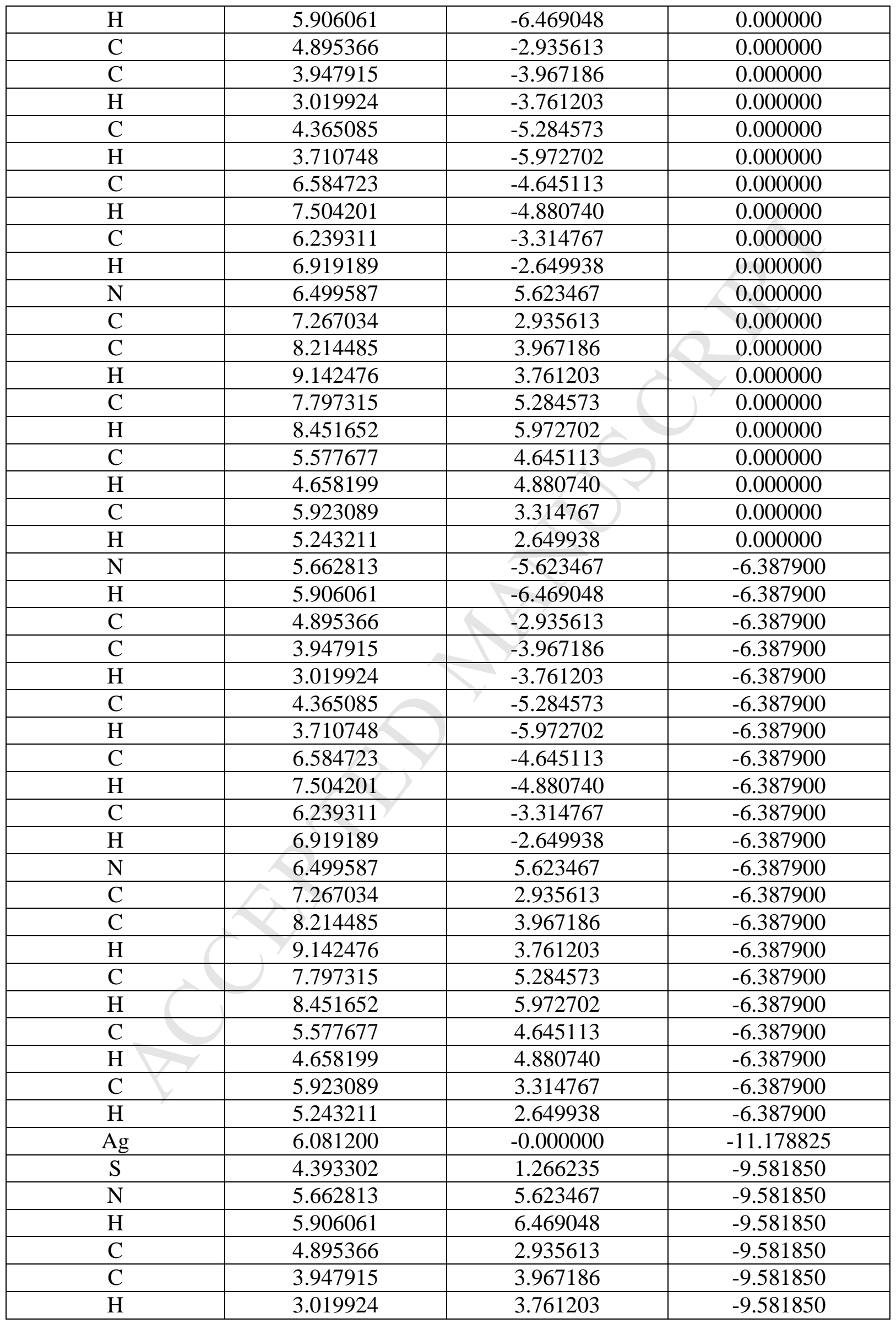


ACCEPTED MANUSCRIPT

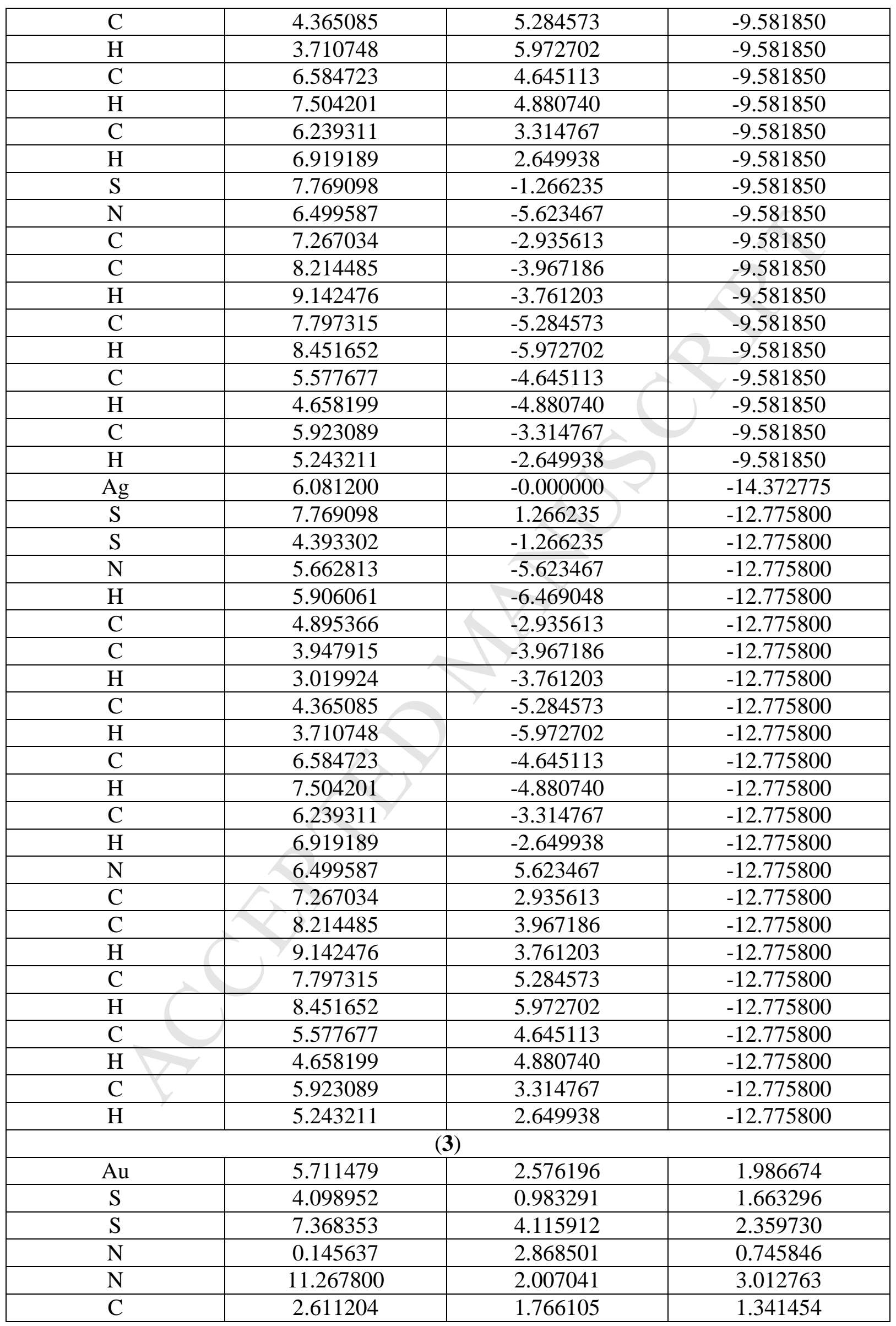


ACCEPTED MANUSCRIPT

\begin{tabular}{|c|c|c|c|}
\hline $\mathrm{C}$ & 1.460224 & 0.945560 & 1.184539 \\
\hline $\mathrm{H}$ & 1.528698 & 0.003409 & 1.289372 \\
\hline $\mathrm{C}$ & 0.252883 & 1.519487 & 0.881393 \\
\hline $\mathrm{H}$ & -0.514162 & 0.970562 & 0.765210 \\
\hline $\mathrm{C}$ & 1.199913 & 3.675409 & 0.934143 \\
\hline $\mathrm{H}$ & 1.093399 & 4.616422 & 0.854017 \\
\hline $\mathrm{C}$ & 2.439847 & 3.149214 & 1.244634 \\
\hline $\mathrm{H}$ & 3.176176 & 3.729960 & 1.392201 \\
\hline $\mathrm{C}$ & 8.823565 & 3.254907 & 2.620142 \\
\hline $\mathrm{C}$ & 8.940099 & 1.845660 & 2.611462 \\
\hline $\mathrm{H}$ & 8.168339 & 1.308100 & 2.473243 \\
\hline $\mathrm{C}$ & 10.166281 & 1.250139 & 2.803766 \\
\hline $\mathrm{H}$ & 10.239843 & 0.303443 & 2.789076 \\
\hline $\mathrm{C}$ & 11.206979 & 3.346963 & 3.032127 \\
\hline $\mathrm{H}$ & 11.998579 & 3.850428 & 3.183032 \\
\hline $\mathrm{C}$ & 10.013513 & 4.000445 & 2.836484 \\
\hline $\mathrm{H}$ & 9.984852 & 4.950550 & 2.845832 \\
\hline $\mathrm{H}$ & -0.592629 & 3.295821 & 0.400633 \\
\hline $\mathrm{H}$ & 12.018111 & 1.556991 & 3.058168 \\
\hline $\mathrm{Au}$ & 5.143978 & 3.106254 & 5.325285 \\
\hline $\mathrm{S}$ & 3.531451 & 4.699159 & 5.001907 \\
\hline $\mathrm{S}$ & 6.800852 & 1.566538 & 5.698342 \\
\hline $\mathrm{N}$ & -0.421864 & 2.813949 & 4.084457 \\
\hline $\mathrm{N}$ & 10.700299 & 3.675409 & 6.351374 \\
\hline $\mathrm{C}$ & 2.043703 & 3.916345 & 4.680065 \\
\hline $\mathrm{C}$ & 0.892723 & 4.736890 & 4.523150 \\
\hline $\mathrm{H}$ & 0.961197 & 5.679041 & 4.627983 \\
\hline $\mathrm{C}$ & -0.314618 & 4.162963 & 4.220005 \\
\hline $\mathrm{H}$ & -1.081663 & 4.711888 & 4.103821 \\
\hline $\mathrm{C}$ & 0.632412 & 2.007041 & 4.272755 \\
\hline $\mathrm{H}$ & 0.525898 & 1.066028 & 4.192628 \\
\hline $\mathrm{C}$ & 1.872345 & 2.533236 & 4.583245 \\
\hline $\mathrm{H}$ & 2.608675 & 1.952490 & 4.730812 \\
\hline $\mathrm{C}$ & 8.256064 & 2.427543 & 5.958753 \\
\hline $\mathrm{C}$ & 8.372598 & 3.836790 & 5.950073 \\
\hline $\mathrm{H}$ & 7.600838 & 4.374350 & 5.811854 \\
\hline $\mathrm{C}$ & 9.598780 & 4.432311 & 6.142377 \\
\hline & 9.672342 & 5.379007 & 6.127687 \\
\hline & 10.639478 & 2.335487 & 6.370738 \\
\hline $\mathrm{H}$ & 11.431077 & 1.832022 & 6.521643 \\
\hline $\mathrm{C}$ & 9.446012 & 1.682005 & 6.175095 \\
\hline $\mathrm{H}$ & 9.417350 & 0.731900 & 6.184443 \\
\hline $\mathrm{H}$ & -1.160131 & 2.386629 & 3.739245 \\
\hline $\mathrm{H}$ & 11.450610 & 4.125459 & 6.396779 \\
\hline $\mathrm{Au}$ & 6.278980 & 3.106254 & -1.351937 \\
\hline $\mathrm{S}$ & 4.666453 & 4.699159 & -1.675315 \\
\hline $\mathrm{S}$ & 7.935855 & 1.566538 & -0.978881 \\
\hline $\mathrm{N}$ & 0.713138 & 2.813949 & -2.592765 \\
\hline
\end{tabular}


ACCEPTED MANUSCRIPT

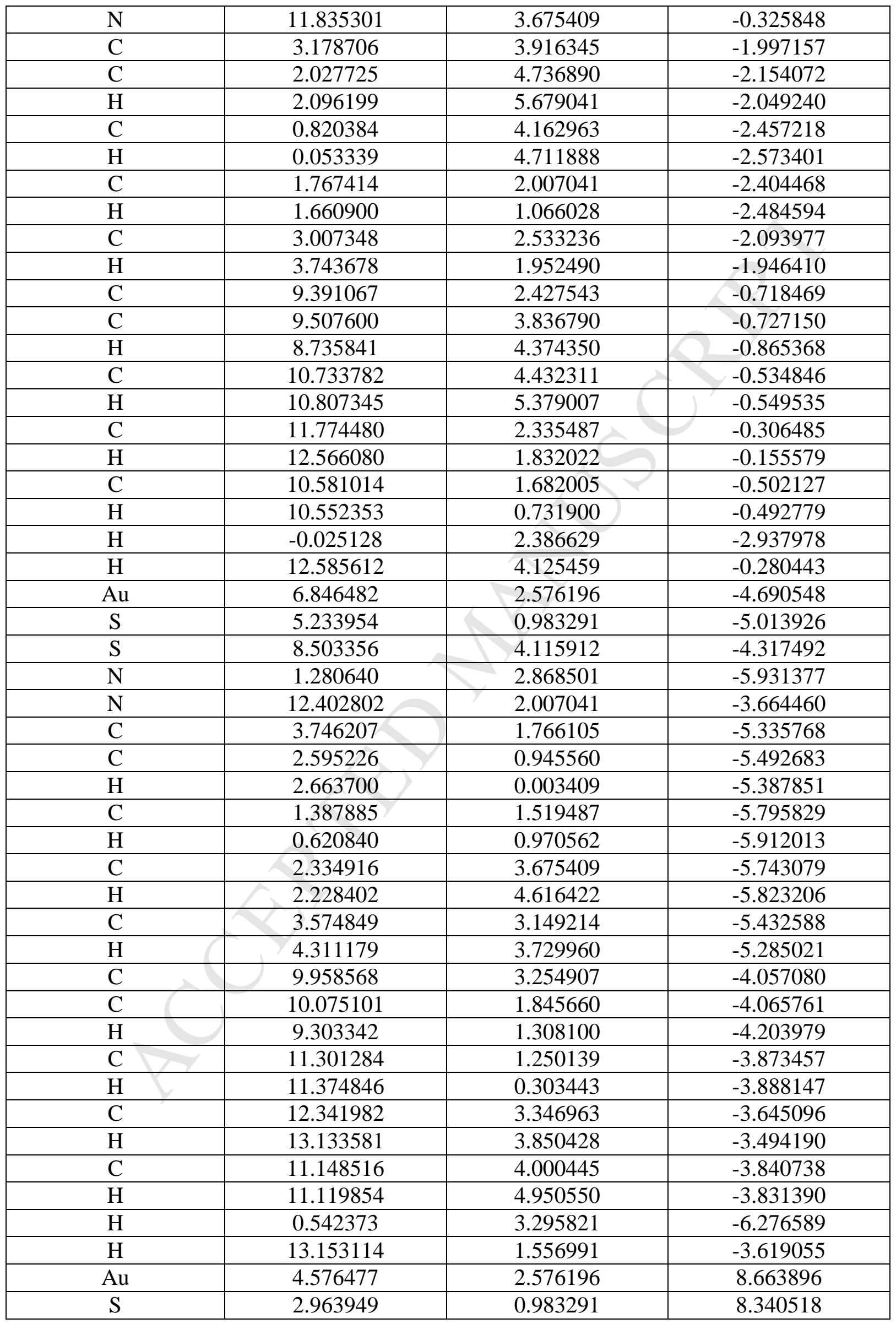




\begin{tabular}{|c|c|c|c|}
\hline S & 6.233351 & 4.115912 & 9.036953 \\
\hline $\mathrm{N}$ & -0.989365 & 2.868501 & 7.423068 \\
\hline $\mathrm{N}$ & 10.132797 & 2.007041 & 9.689985 \\
\hline $\mathrm{C}$ & 1.476202 & 1.766105 & 8.018676 \\
\hline $\mathrm{C}$ & 0.325222 & 0.945560 & 7.861762 \\
\hline $\mathrm{H}$ & 0.393696 & 0.003409 & 7.966594 \\
\hline $\mathrm{C}$ & -0.882120 & 1.519487 & 7.558616 \\
\hline $\mathrm{H}$ & -1.649165 & 0.970562 & 7.442432 \\
\hline $\mathrm{C}$ & 0.064911 & 3.675409 & 7.611366 \\
\hline $\mathrm{H}$ & -0.041603 & 4.616422 & 7.531239 \\
\hline $\mathrm{C}$ & 1.304844 & 3.149214 & 7.921857 \\
\hline $\mathrm{H}$ & 2.041174 & 3.729960 & 8.069423 \\
\hline $\mathrm{C}$ & 7.688563 & 3.254907 & 9.297364 \\
\hline $\mathrm{C}$ & 7.805096 & 1.845660 & 9.288684 \\
\hline $\mathrm{H}$ & 7.033337 & 1.308100 & 9.150466 \\
\hline $\mathrm{C}$ & 9.031279 & 1.250139 & 9.480988 \\
\hline $\mathrm{H}$ & 9.104841 & 0.303443 & 9.466298 \\
\hline $\mathrm{C}$ & 10.071977 & 3.346963 & 9.709349 \\
\hline $\mathrm{H}$ & 10.863576 & 3.850428 & 9.860254 \\
\hline $\mathrm{C}$ & 8.878511 & 4.000445 & 9.513706 \\
\hline $\mathrm{H}$ & 8.849849 & 4.950550 & 9.523055 \\
\hline $\mathrm{H}$ & -1.727632 & 3.295821 & 7.077856 \\
\hline & 10.883109 & 1.556991 & 9.735390 \\
\hline
\end{tabular}


Table S2. Selected bond lengths $[\AA]$ and angles $\left[{ }^{\circ}\right]$ for 1-3.

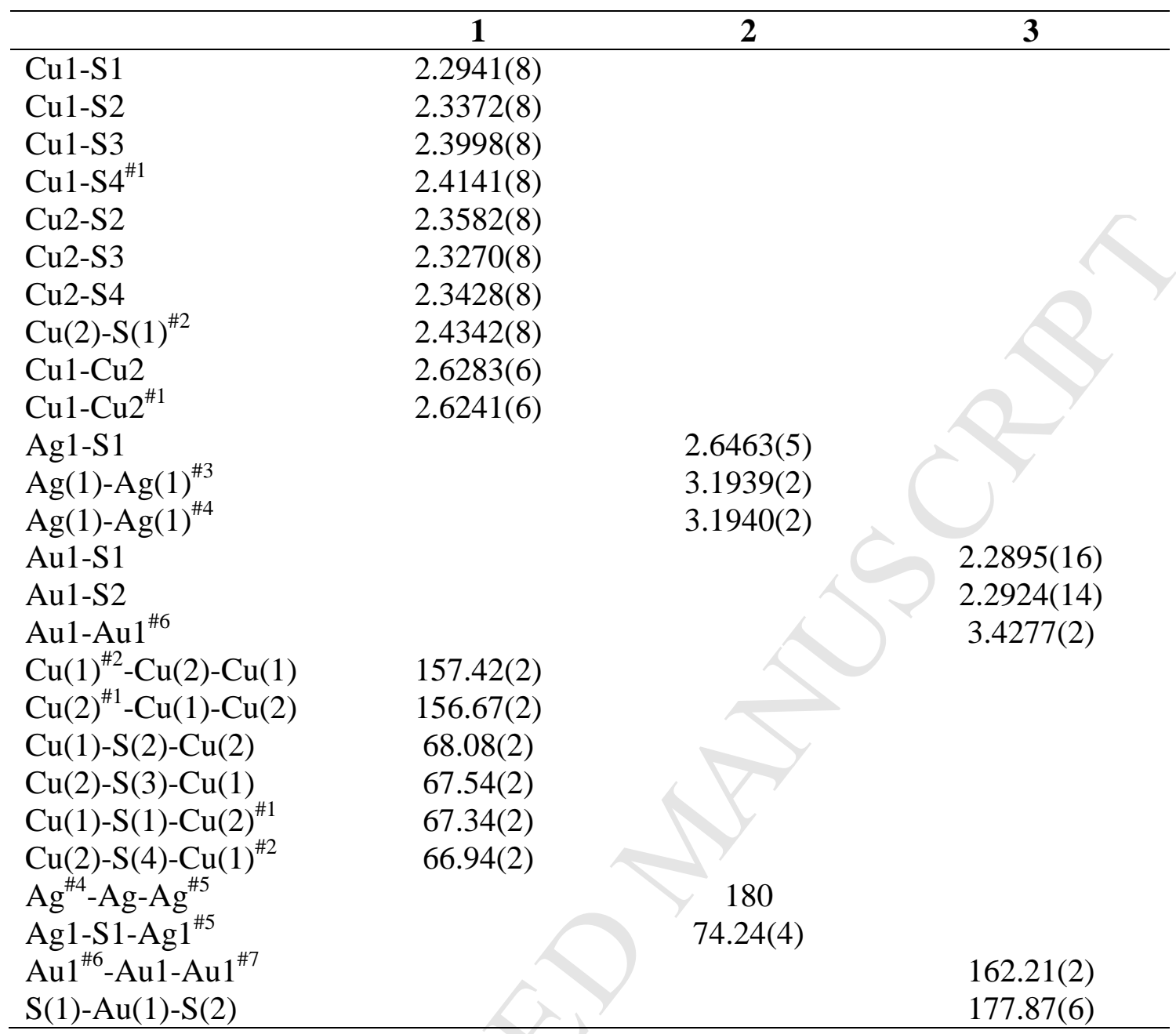

Symmetry transformations used to generate equivalent atoms:

$\# 1-x+1 / 2, y+1 / 2,-z+1 / 2, \# 2-x+1 / 2, y-1 / 2,-z+1 / 2, \# 3-x+1, y, z-1 / 2, \# 4-x+1,-y,-z, \# 5-x+1,-y,-z+1, \# 6 x,-$ $y+1 / 2, z+1 / 2, \# 7 x,-y+1 / 2, z-1 / 2$ 
Table S3. Hydrogen bonds $\left(\AA{ }^{\circ}{ }^{\circ}\right)$ for $\mathbf{1}$.

\begin{tabular}{lllll}
\hline$D-H \cdots A$ & $d(D-H)$ & $d(H \cdots A)$ & $d(D \cdots A)$ & $<(D H A)$ \\
\hline$N 1-H 1 \cdots S 4^{\# 1}$ & 0.82 & 2.53 & $3.318(3)$ & 161.3 \\
$N 3-H 3 \cdots C l 1$ & 0.80 & 2.72 & $3.286(3)$ & 129.1 \\
$N 3-H 3 \cdots C l 4$ & 0.80 & 2.54 & $3.147(3)$ & 133.1 \\
$N 2-H 2 \cdots C l 4^{\# 3}$ & 0.95 & 2.47 & $3.201(3)$ & 133.8 \\
$N 2-H 2 \cdots O I^{\# 3}$ & 0.95 & 2.28 & $2.994(5)$ & 131.6 \\
$N 4-H 4 \cdots C l 2$ & 0.83 & 2.68 & $3.373(3)$ & 143.1 \\
$O 1-H 1 A \cdots C l 2^{\# 4}$ & 0.97 & 2.65 & $3.442(6)$ & 139.5 \\
\hline
\end{tabular}

Symmetry transformations used to generate equivalent atoms:

$\# 1:-x+3 / 2, y+1 / 2,-z+1 / 2 \quad \# 2: x+1 / 2,-y+1 / 2, z-1 / 2$

$\# 3: x-1 / 2,-y+1 / 2, z-1 / 2 \quad \# 4:-x+1,-y,-z+1$

Table S4. Hydrogen bonds $\left(\AA^{\circ},{ }^{\circ}\right)$ for 2.

\begin{tabular}{lllll}
\hline$D-H \cdots A$ & $d(D-H)$ & $d(H \cdots A)$ & $d(D \cdots A)$ & $<(D H A)$ \\
\hline$N 1-H 1 \cdots N I^{\# l}$ & 0.88 & 1.80 & $2.675(4)$ & 176.7 \\
\hline
\end{tabular}

Symmetry transformations used to generate equivalent atoms: $\# 1: X+1,-y+1, z$.

Table S5. Hydrogen bonds for $\left(\AA^{\circ},{ }^{\circ}\right)$ for 3 .

\begin{tabular}{lllll}
\hline$D-H \cdots A$ & $d(D-H)$ & $d(H \cdots A)$ & $d(D \cdots A)$ & $<(D H A)$ \\
\hline$N 2-H 2 \cdots C l l^{\# 1}$ & $0.87(11)$ & $2.26(10)$ & $3.054(5)$ & $151(9)$ \\
$N 1-H 1 \cdots C l 1^{\# 2}$ & $0.92(8)$ & $2.15(8)$ & $3.057(6)$ & $172(6)$ \\
\hline
\end{tabular}

Symmetry transformations used to generate equivalent atoms: \#1: $-x+1, y-1 / 2,-z+1 / 2, \# 2:-x,-y+1,-z$ 


\section{Highlights}

Three polymeric group 11 transition metal polymers featuring metallophilic interactions were obtained directly via self-assembly of metal ions and 4-pyridinethiol ligands. The behavior of the ligand was depending on the nature of the metal center and the reaction conditions. With copper and silver, the 4pyridinethiol ligands were acting as bridging ligands bringing metal centers together. In the gold polymer 4pyridinethiol ligands were terminal ligands and the polymer was formed via non-covalent aurophilic contacts. 